\title{
Trans-Atlantic dinoflagellate cyst stratigraphy across the Cenomanian-Turonian (Cretaceous) Stage boundary
}

\author{
PAUL DODSWORTH \\ Centre for Palynology, Dainton Building, University of Sheffield, Sheffield S3 7HF, UK \\ Current address: Millennia Ltd, Unit 3, Weyside Park, Newman Lane, Alton, Hampshire GU34 2PJ, UK. email: MillenniaSC@msn.com
}

\begin{abstract}
The principal palynological proxy for the Cenomanian-Turonian Stage boundary, the top of consistent/common Litosphaeridium siphoniphorum (a dinoflagellate cyst), occurs in Greenhorn Bed 73 at the international stratotype section, west of Pueblo, Colorado, USA. This datum occurs in the same position, as indicated by planktonic foraminifera (a few beds higher than the range top of $R$. cushmani), ammonites (upper part of the $S$. gracile/M. geslinianum Zone) and geochemistry (immediately below maximum $\delta^{13} \mathrm{C}$ values), at Pueblo (Western Interior Basin) and localities in southern England (WessexParis Basin) and northern Germany (Lower Saxony Basin). Of over 100 dinoflagellate cyst taxa recorded from Pueblo and a correlative section at Lulworth, southern England, possibly as few as six do not range into the Turonian. In the uppermost Cenomanian - lowermost Turonian succession at Pueblo, there are no consistent absences of any common taxa (with four exceptions) and there is no evidence for a collapse in cyst-forming dinoflagellate populations during the Cenomanian-Turonian boundary mass extinction interval/'oceanic anoxic event'. However, the composition of palynological assemblages from the Upper Cenomanian appears to refiect palaeoenvironmental stress and/or an increase in the supply of land-derived and relatively nearshore palynomorphs. J. Micropalaeontol. 19(1): 69 84, May 2000.
\end{abstract}

\section{INTRODUCTION}

Dinoflagellate cysts are widely used in Upper Cretaceous stratigraphy. They are an important fossil group applied to hydrocarbon exploration biostratigraphy of the Shetland Group and Chalk Group in the North Sea Basin (Costa \& Davey, 1992). Following recent progress in defining the Upper Cretaceous stage and substage boundaries (Rawson et al., 1996), it is now apt to begin detailed calibration of dinoflagellate cyst ranges and zonations at the proposed international stratotypes and correlative reference sections.

The Cenomanian-Turonian boundary (i.e., the base of the Turonian Stage) has become one of the least controversial among the Cretaceous stage boundaries (Bengtson, 1996). Considerable international attention has been given to the boundary in recent years due to the widespread occurrence of anomalously organic carbon-rich strata ('oceanic anoxic event', Schlanger \& Jenkyns, 1976), and, what some workers consider to be a major ('second order') faunal mass extinction (e.g., Raup \& Sepkoski, 1982; Kaufiman, 1984a; Harries, 1993).

It has been known for some time that several dinoflagellate cysts have widespread range bases and tops around the Cenomanian-Turonian boundary level (e.g., Clarke \& Verdier, 1967; Foucher, 1979, 1982) and are, therefore, of potential stratigraphical use in differentiating Upper Cenomanian from Lower Turonian. This paper calibrates the distribution of dinoflagellate cysts, and other palynomorphs, at the proposed Cenomanian-Turonian boundary stratotype (Kennedy \& Cobban, 1991; Bengtson, 1996) at Rock Canyon Anticline, west of Pueblo, Colorado, USA (Fig. 1), and compares their distribution with that at Durdle Cove, Lulworth, Dorset, southern England (Fig. 2). These localities are abbreviated to Pueblo and Lulworth respectively in the text. Both sections are from basinal areas. Some of the limestone and bentonite beds shown in Fig. 1 can be traced laterally across wide areas of the Western Interior Basin (Hattin, 1975). The individual beds of the Plenus Marls (Fig. 2) can be traced across the Wessex-Paris Basin (Jefferies, 1963).
A marked decrease in the diversity and abundance of dinoflagellate cysts has been reported from the uppermost Cenomanian-lowermost Turonian at some localities (e.g., Jarvis et al., 1988; Nuñez-Betelu \& Hills, 1995; Tocher \& Jarvis, 1995; FitzPatrick, 1996; Lamolda \& Mao, 1999). It has been suggested that a major reduction in primary productivity, chiefly of coccolithophores but including that of dinoflagellates, could have led to starvation higher up the food chain and the marked turnovers of foraminifera and molluscs documented from the interval (Lamolda et al., 1994; Paul \& Mitchell, 1994).

A thorough assessment of dinoflagellate cyst diversity and abundance fluctuations across the stage boundary is attempted at Pueblo. Information from other fossil groups is incorporated to aid palaeoenvironmental interpretation. At Lulworth, the investigation is focused on the succession through which the suspected collapse of cyst-forming dinoflagellate populations occurred in the southern England area, i.e., the upper part of the Plenus Marls.

\section{PREVIOUS WORK AND SAMPLING STRATEGIES}

There have been two previous palynological investigations of the Pueblo section (for location maps, see Kennedy \& Cobban, 1991, figs 1 \& 7). Courtinat (1993) studied 21 spot samples from the lower Bridge Creek Member ( $S$. gracile to lower $W$. coloradoense Zones). He focused on possible relationships between palynofacies and lithology and did not discuss the dinoflagellate cyst biostratigraphy of the section. Li \& Habib (1996) studied 14 spot samples from the lower Bridge Creek Member (upper $S$. gracile to $W$. coloradoense Zones). They reported palynofacies and the ratio of chorate to proximochorate-proximate dinoflagellate cysts, although no taxa were listed for the section. Neither study reported the relative or absolute abundance of palynomorph taxa. Here, a quantitative documentation is given of the palynomorphs from 53 samples (BCseries) that were channelled through $9 \mathrm{~m}$ of the lower and middle Bridge Creek Member (S. gracile to lower M. nodosoides Zones). The proposed Global boundary Stratotype Section and Point 


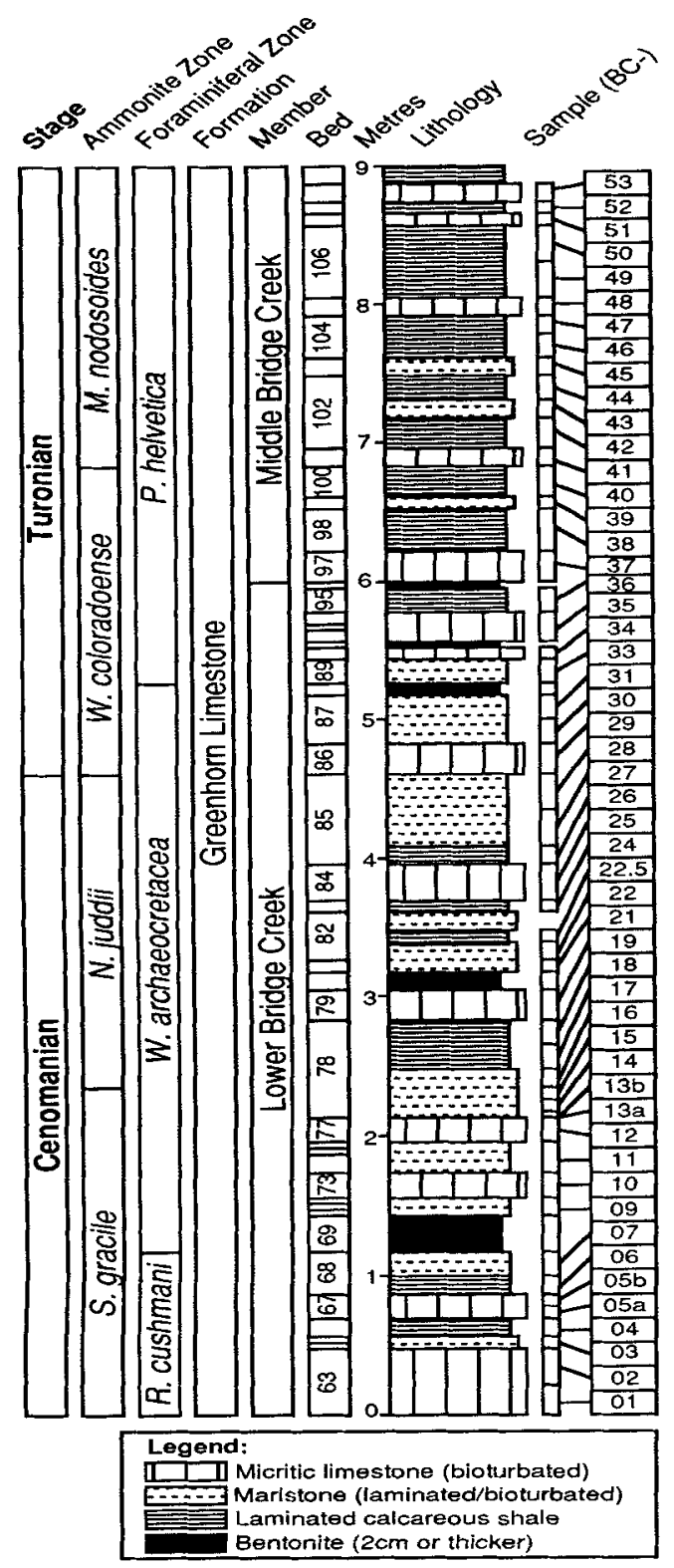

Fig. 1. Lithology, stratigraphy and sample positions at Pueblo. The lithostratigraphy is from Cobban \& Scott (1972) and Elder \& Kirkland (1985).

(GSSP or 'golden spike') for the Cenomanian-Turonian boundary is located approximately mid-way through the sampled section, at the base of Bed 86 (Bengtson 1996). The criterion of sampling was lithology. The thickness of channelled samples varies from $50 \mathrm{~mm}$ to $300 \mathrm{~mm}$, depending on the thickness of rock layers (Fig. 1).

The section at Lulworth (Fig. 3) is located near the northeast corner of Durdle Cove at the foot of the cliff. The Plenus Marls (Fig. 2) are vertical here. Jefferies (1963) noted that despite great regional tectonic disturbances, the Plenus Marls seem to be complete at Durdle Cove and corroborated this with macrofossil evidence. Fourteen spot samples (DD-series) were collected over approximately $8.5 \mathrm{~m}$ with the highest density of sampling in the upper part of the Plenus Marls.

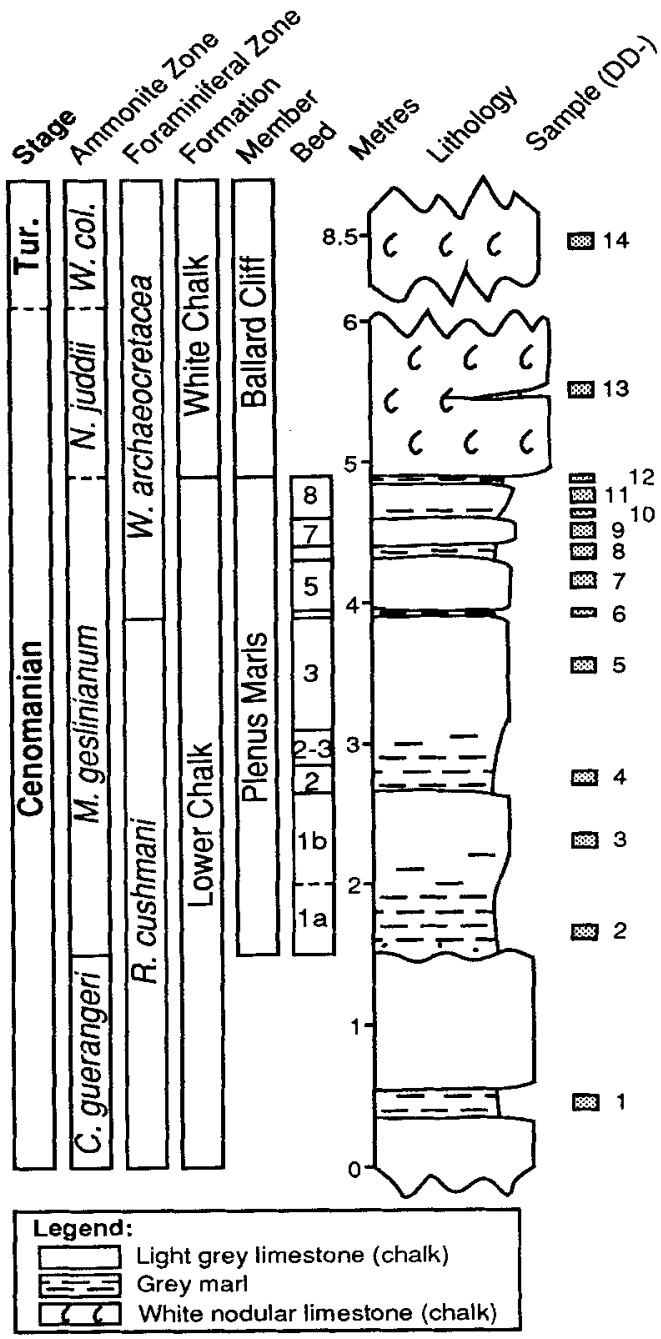

Fig. 2. Lithology, stratigraphy and sample positions at Lulworth. The lithostatigraphy is from Jefferies (1963) and Gale (1996).

\section{PALYNOLOGICAL METHODS \& CONCEPTS}

\section{Laboratory processing}

Five grams, or multiples thereof, of crushed, dried sediment from each rock sample was dissolved in hydrochloric acid $(\mathrm{HCl}$ $35 \%$ ) and hydrofluoric acid (HF $40 \%$ ) in order to remove carbonate and silicate minerals respectively. Preparations were sieved with $10 \mu \mathrm{m}$ mesh. Palynomorphs and brown and black wood fragments (vitrinite and inertinite) dominate the $>10 \mu \mathrm{m}$ kerogen fraction in the lower part of the succession at Pueblo ( $S$. gracile, lower $N$. juddii and lower $W$. coloradoense Zones). Some of these preparations contained transparent, 'cloudy' amorphous organic matter (AOM) which was removed by a 'nitric wash', i.e., two minutes of oxidation with nitric acid $(70 \%$ $\mathrm{HNO}_{3}$ ). In the upper $N$. juddii Zone and upper $W$. coloradoense $-M$. nodosoides Zones, the $>10 \mu \mathrm{m}$ kerogen fraction from the shale samples is dominated by dark coloured, clumped AOM. Fragments of this material outnumber palynomorphs at a ratio of several hundreds or thousands to one. Between three minutes and 36 hours of oxidation with Schulze's solution $(70 \%$ 


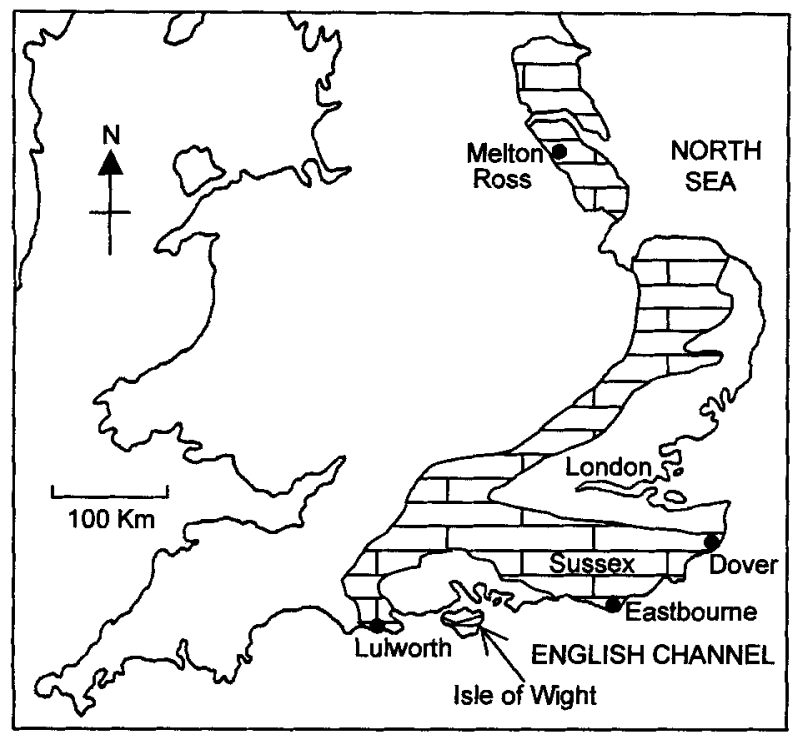

Fig. 3. Sketch map of UK Cretaceous outcrop (shaded), showing the location of the English sections and areas referred to in the text.

$\mathrm{HNO}_{3}$ supersaturated with potassium chlorate, $\mathrm{KClO}_{3}$ ), followed by one subsequent rinse with $2 \%$ potassium hydroxide $(\mathrm{KOH})$ solution, were used to liberate palynomorphs from the AOM (Fig. 4). The $>10 \mu \mathrm{m}$ kerogen fraction from the interbedded limestones at these levels is composed of palynomorphs, brown and black wood fragments, and dark coloured, clumped AOM. In general, oxidation of preparations from such limestones was restricted to a 'nitric wash'. The $>10 \mu \mathrm{m}$ kerogen fractions from the Lulworth samples are dominated by dinoflagellate cysts; no oxidative treatment was given.

All preparations were stained with Safranine O solution (red stain). Approximately equal portions of organic residues from each sample were strewn over four $22 \times 22 \mathrm{~mm}$ cover slips, dried, and mounted onto microscope slides using Petropoxy 154.

\section{Quantitative parameters}

To obtain an estimate of the number of palynomorphs on cover slips, the number in 1/22 of the area of each was counted (in a traverse corresponding to the ' $M$ '-row of an England Finder) and multiplied by 22 . To give an estimate of absolute abundance, i.e., the number of palynomorphs per gram in each sample (Figs. 4 and 5), the mean number of palynomorphs per cover slip was divided by the mass of the rock material represented on each cover slip. Relative abundance was estimated by counting the first 300 palynomorphs identified $(0.3 \%=1$ specimen; $0.7 \%=2$ specimens; $1 \%=3$ specimens etc.). Two or more cover slips were carefully scanned for each of the samples. On the range charts (Figs 6 and 7), taxa that were not located in the 300 count are listed in the $<0.3 \%$ category. The relative abundance of taxa in assemblages is referred to as 'rare' $(<0.3 \%)$, 'common' $(0.3 \%-10.0 \%)$ or 'abundant' $(>10 \%)$ in the text.

Gonyaulacineae and Peridiniineae are the main categories (Suborders) of dinoflagellate cysts recorded. Their relative numerical importance is thought to be a useful parameter in palaeoenvironmental interpretation (e.g., Harland, 1973). Here,

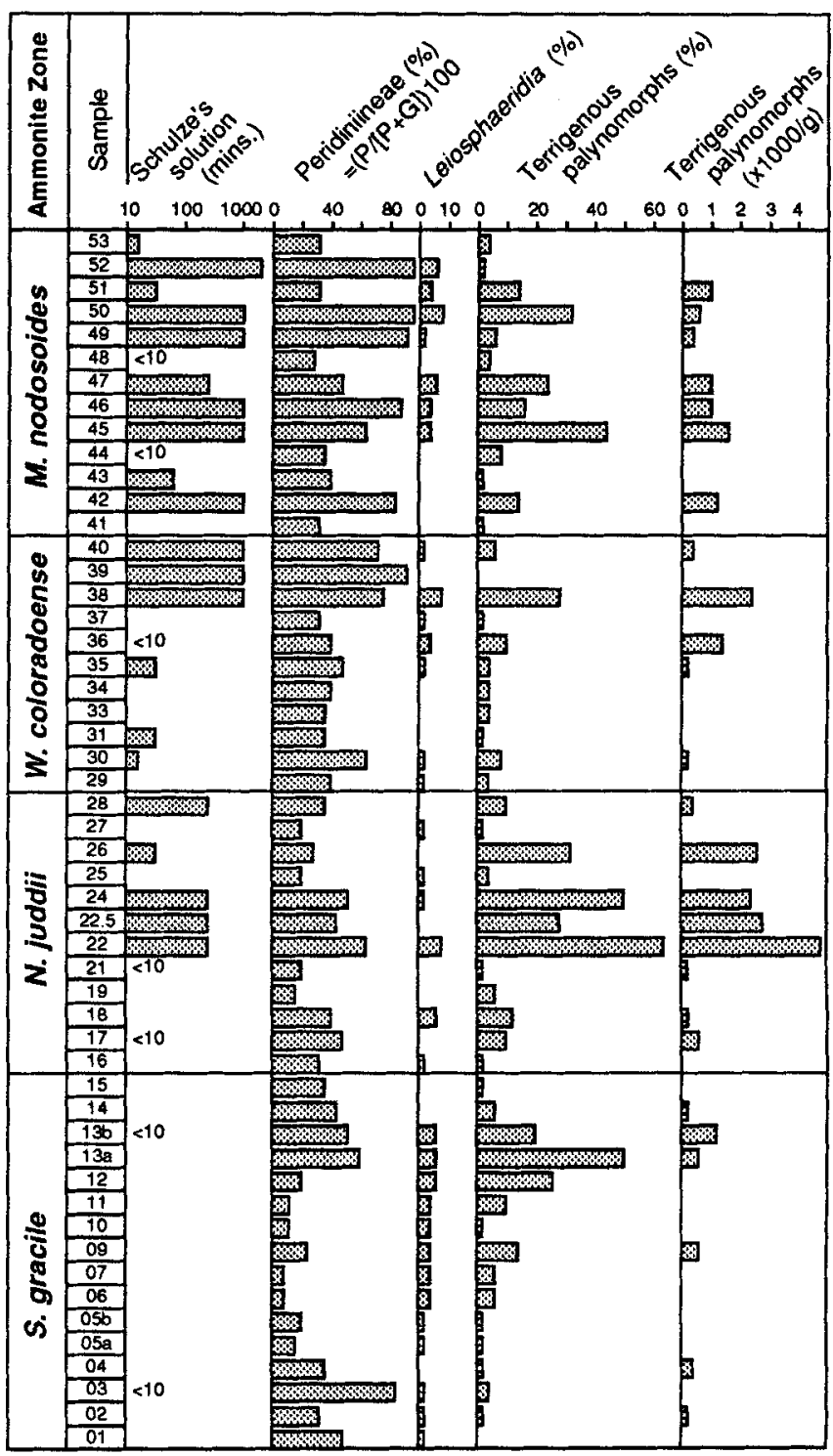

Fig. 4. Duration of oxidation, 'Peridiniineae (\%)' and the abundance of Leiosphaeridia spp. and terrigenous palynomorphs at Pueblo.

parameters called 'Peridiniineae (\%)' and 'Gonyaulacineae (\%)' are used. The number of Peridiniineae present in counts from each sample $(P)$ was divided by the sum of Peridiniineae and Gonyaulacineae in the same counts $(P+G)$ and multiplied by 100 to give 'Peridiniineae $(\%)=(P /[P+G]) 100$. Conversely 'Gonyaulacineae $(\%) '=(G /[P+G]) 100$ or $100-$ 'Peridiniineae $(\%)$ '.

The observation that oxidation with Schulze's solution and $\mathrm{KOH}$ selectively removes gonyaulacineaen dinoflagellate cysts (Dodsworth, 1995) was made after all of the palynological analyses documented here had been completed. Gonyaulacineae $(\%)$ values in organic residues from Pueblo samples BC-48 and 50 (Fig. 1), were shown experimentally to progressively decrease in response to increases in the duration of oxidative treatment (Dodsworth, 1995, Fig. 1). In Figure 4, the durations of oxidation in Schulze's solution are plotted on a logarithmic 


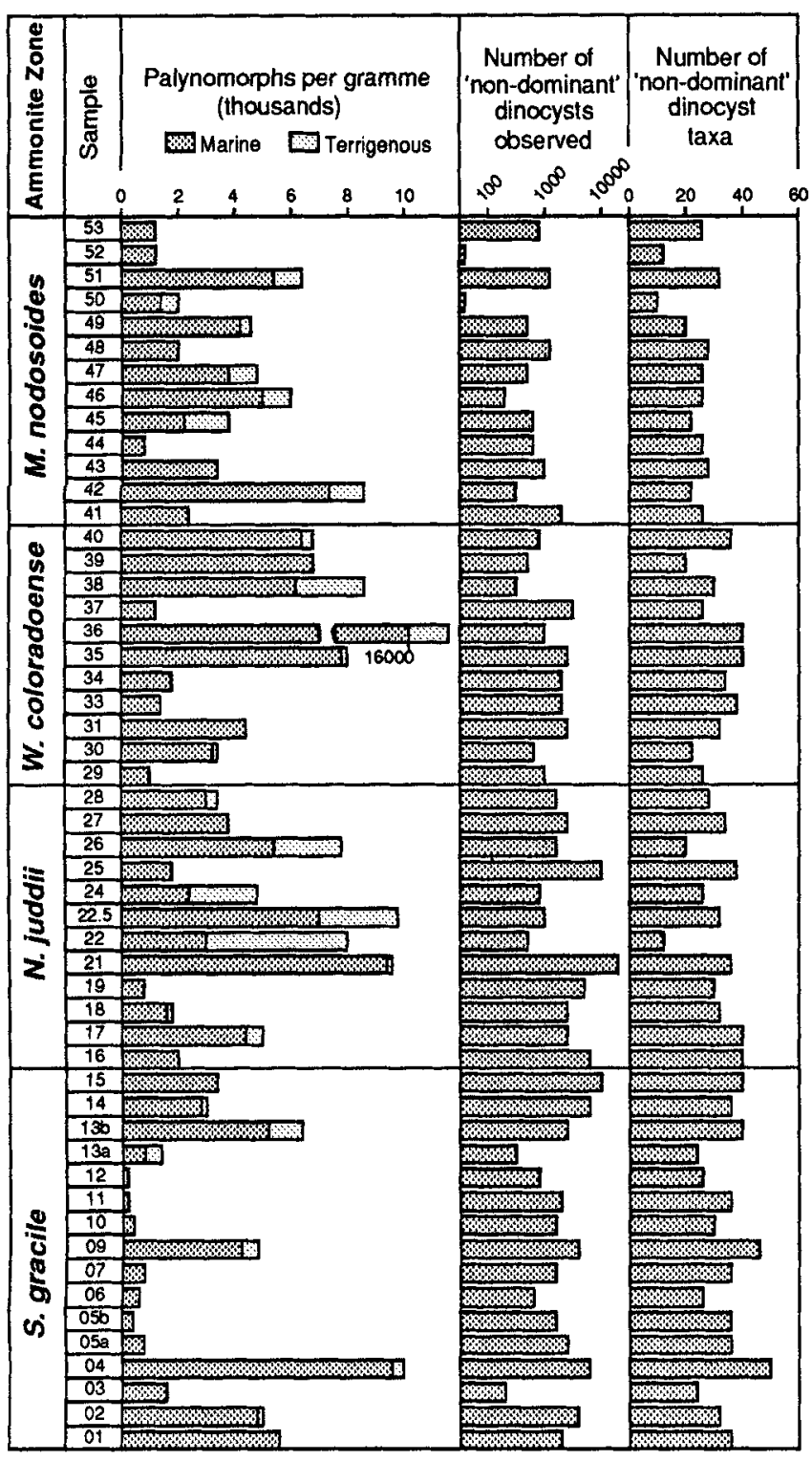

Fig. 5. Absolute abundance (concentration) and dinoflagellate cyst ('dinocyst') diversity data from Pueblo.

scale while the corresponding Peridiniineae (\%) values are plotted on a linear scale. In the shale preparations of the upper $W$. coloradoense and $M$. nodosoides Zones, there is clearly a correlation between relatively long oxidations and raised values of Peridiniineae (\%), from background values of just under $40 \%$ to over $60-80 \%$ (Fig. 4). Oxidation with Schulze's solution and $\mathrm{KOH}$ has made possible the stratigraphical documentation of palynomorphs given in Figure 6. However, its use clearly renders the proportion of Peridiniineae useless in palaeoenvironmental interpretation at Pueblo.

Four factors influencing the number of taxa recorded in each of a set of samples are: the number of taxa present (diversity); the state of preservation; the number of specimens observed; and fluctuations in the dominance of one or more taxa. In order to compensate for fluctuations in dominance in the interpretation of dinoflagellate cyst diversity at Pueblo and Lulworth, the number of 'non-dominant' specimens observed in each sample has been plotted against the corresponding number of "nondominant' taxa recorded (Figs $5 \& 8$ ). Four taxa are regarded as dominant in the present study; Palaeohystrichophora infusorioides, Spiniferites Group (Fig. 9), Subtilisphaera spp. and Isabelidinium spp. (Fig. 10). In Figures 5 and 8, values for these fossils have been subtracted both from the sum of dinoflagellate cyst specimens observed and from the number of dinoflagellate cyst taxa, to give the corresponding 'non-dominant' values for each sample. This is a new graphical technique for interpreting diversity. It is discussed further below.

\section{Access to slides and data}

All microscope slides used in the present study are curated in the collections of the Centre for Palynology, University of Sheffield. All data used in the preparation of Figures 4-11, along with lithological descriptions of the samples analysed, have been tabulated and can be obtained from the Geological Society Library or the British Library Document Supply Centre, Boston Spa, Wetherby, West Yorkshire LS23 7BQ, UK as Supplementary Publication No. SUP 18147 (14 pages).

\section{BIOSTRATIGRAPHY}

Most of the dinoflagellate cyst taxa recorded in the present study have stratigraphical ranges much broader than Upper Cenomanian to Lower Turonian. The distribution of well documented, regional/inter-regional range bases and tops around the stage boundary is discussed below with reference to the Pueblo and Lulworth sections, followed by a review of local range tops.

\section{Upper Cenomanian-Lower Turonian range bases}

Three dinoflagellate cysts are reported to have Lower Turonian range bases in northwest Europe; Heterosphaeridium difficile, Senoniasphaera rotundata and Florentinia buspina (Davey \& Verdier, 1976; Foucher 1980, 1981; Tocher \& Jarvis, 1987; Tocher in Jarvis et al., 1988; Costa \& Davey, 1992; FitzPatrick, 1995). S. rotundata and $F$. buspina sensu stricto were not recorded at Pueblo or Lulworth. An isolated specimen (Plate 1, fig. 7) and several fragments assignable to $H$. difficile were recovered from one sample (BC-36) at Pueblo, in the $W$. coloradoense Zone. The taxon was not observed at Lulworth. It is a more consistent and common component of assemblages from the Middle Turonian to Santonian.

\section{The top of consistent/common Litosphaeridium siphoniphorum} Litosphaeridium siphoniphorum (e.g., Plate 1, fig. 1) is consistent/ common up to mid-levels of the $S$. gracile Zone at Pueblo (Bed 73) and the M. geslinianum Zone at Lulworth (Bed 6), as shown in Figures 6 and 7. In the upper parts of these zones, it is present but only at an abundance of about one specimen per ten thousand. Above the S. gracile Zone (i.e., above Greenhorn Bed 78), three specimens only were recorded at Pueblo. Clarke \& Verdier (1967), Foucher (1982) and Marshall \& Batten (1988) reported the sporadic retrieval of specimens from the Turonian of the Isle of Wight, the Touraine area of France and the Münster Basin of Germany.

Litosphaeridium siphoniphorum tends to be consistent/common between its range base in the Upper Albian (Davey \& 
Verdier, 1971, pp. 44-50) and the Upper Cenomanian (e.g., Clarke \& Verdier, 1967). The top of consistent/common $L$. siphoniphorum has been documented from the Upper Cenomanian at other localities in the western interior of the USA (Li \& Habib, 1996) and southern England (Clarke \& Verdier, 1967; Davey, 1969; Hart et al., 1987; Tocher, 1992), the Witch Ground Graben, central North Sea (Harker et al., 1987), France (Foucher, 1979, 1980; Courtinat et al., 1991), northern Spain (Mao \& Lamolda, 1999), northern Germany (Marshall \& Batten, 1988), eastern USA (Aurisano, 1989), Australia (Morgan, 1980; McMinn, 1988), Deep Sea Drilling Project holes (R. Davey, pers. comm., 1992) and Japan (H. Kurita, pers. comm., 1997). In the western interior of the USA, Li \& Habib (1996) reported the range top of $L$. siphoniphorum to occur in the $S$. gracile Zone while in southern England, it has been reported to occur in Plenus Marls Bed 6 at Eastbourne, Sussex (Tocher, 1992) and between Beds 3 and 7 at Culver Cliff, Isle of Wight (Hart et al., 1987).

Scholle \& Arthur (1980) documented a widespread carbon isotope $\left(\delta^{13} \mathrm{C}\right)$ anomaly across the Cenomanian-Turonian boundary. Widespread burial of organic matter (which is highly enriched in $\delta^{12} \mathrm{C}$ ) during the interval would have left sea water relatively enriched in $\delta^{13} \mathrm{C}$. Carbonate-secreting organisms, chiefly coccolithophores, are thought to have recorded this enrichment as they secreted their skeletons in equilibrium with sea water (Paul \& Mitchell, 1994). Gale et al. (1993) found that the shape of the $\delta^{13} \mathrm{C}$ anomaly was similar at Pueblo and Eastbourne and that the component peaks and troughs occurred in the same positions relative to eight successive biostratigraphical markers (see also Hart \& Leary, 1991). They considered the consistent relationship between two independent phenomena, one geochemical, the other biostratigraphical, to provide evidence for the likely synchroneity of both the biostratigraphical markers and the $\delta^{13} \mathrm{C}$ anomaly in the two areas (on a scale of tens of thousands of years).

The top of consistent/common L. siphoniphorum occurs in the same position, relative to the eight other biostratigraphical markers and $\delta^{13} \mathrm{C}$ anomalies, at Pueblo and Eastbourne. The range top of the zonal planktonic foraminiferan Rotalipora cushmani occurs a few beds lower at Pueblo (Bed 67, Leckie, 1985) and in southern England (Bed 3, Carter \& Hart, 1977; Leary \& Peryt, 1991). In Colorado, southern England and northern Germany (cf. Hilbrecht et al., 1986, Fig. 1; Marshall \& Batten, 1988, figs 1-3), the top of consistent/common $L$. siphoniphorum occurs immediately below the level of maximum $\delta^{13} \mathrm{C}$ values (i.e., the 'plateau' phase of Paul \& Mitchell, 1994). It is thus a readily identifiable, practicably isochronous, widespread palaeontological event that may be used as a proxy for the intra-Upper Cenomanian Stage.

\section{Upper Cenomanian-Lower Turonian range tops}

Adnatosphaeridium tutulosum and Carpodinium obliquicostatum have Upper Cenomanian range tops in western Europe (Foucher, 1980; Marshall \& Batten, 1988). In northern Germany (at Wünstorf and Misburg), Marshall \& Batten (1988) noted that both taxa have range tops above consistent/common $L$. siphoniphorum but below the Cenomanian-Turonian boundary. This may also be the case in southern England, as they were retrieved from the Ballard Cliff Member (in DD-13 [Plenus
Marls $+0.5 \mathrm{~m}$ ], but not in DD-14 [Plenus Marls $+3.5 \mathrm{~m}$ ]) at Lulworth while $L$. siphoniphorum was not recorded above the Plenus Marls (Fig. 7). At Pueblo, both taxa have range tops in Bed 78, again above consistent/common L. siphoniphorum (Fig. 6). A. tutulosum (e.g., Plate 1, fig. 2) is common in the $S$. gracile Zone at Pueblo and was not found above sample BC-18 (lower N. juddii Zone). C. obliquicostatum (e.g., Plate 1, fig. 3) is relatively rare at Pueblo; only two specimens were recorded (from samples BC-11 and -14).

Gonyaulacysta cassidata disappears at or below the top of consistent/common L. siphoniphorum in western Europe (e.g., Clarke \& Verdier, 1967; Foucher, 1979, 1980; Marshall \& Batten, 1988) but continues up into the Turonian in the western interior of the USA (Li \& Habib, 1996). It has a Bed 5 range top at Lulworth (this paper). An isolated specimen was found at Pueblo (from sample BC-16). Microdinium setosum has not previously been recorded above the Cenomanian in western Europe. At Lulworth, it has a Bed 7 range top (this paper). It has not been reported from the western interior of the USA.

Dapsilidinium ambiguum has been recorded from the Cenomanian, Turonian and Coniacian of the Paris Basin (Foucher, 1979) and throughout the Upper Cenomanian and Lower Turonian at Pueblo (Fig. 6). It has a $M$. geslinianum Zone range top in southern England (e.g., Clarke \& Verdier, 1967). At Lulworth, it was not found above Plenus Marls Bed 8 (Fig. 7).

Psaligonyaulax deflandrei is known to occur throughout the Cenomanian, Turonian and Coniacian in the North Sea Basin (Costa \& Davey, 1992). It has a $M$. geslinianum Zone range top in southern England and northern Germany (Clarke \& Verdier, 1967; Marshall \& Batten, 1988). At Lulworth, it was not recorded above Plenus Marls Bed 7 (Fig. 7).

According to Li \& Habib (1996), Achomosphaera sagena (e.g., Plate 1, fig. 5) and Surculosphaeridium? longifurcatum have regional (western interior of USA) range tops in the $N$. juddii Zone. However, at Pueblo, their ranges were found to extend into the Zones of $W$. coloradoense and $M$. nodosoides respectively (Fig. 6, this paper). Endoscrinium campanula was reported by $\mathrm{Li} \&$ Habib (1996) to have a regional range top in the lower $W$. coloradoense Zone. Though rare at Pueblo, it ranges into the $M$. nodosoides Zone (Fig. 6, this paper). The comparatively high stratigraphical occurrences of $S$ ? longifurcatum and E. campanula at Pueblo does not support their utility in regional stratigraphy, as suggested by Li \& Habib. However, from the available evidence, the range top of $A$. sagena seems to approximately coincide with the stage boundary on a regional scale. In the North Sea Basin, $A$. sagena, $E$. campanula and $S$ ? longifurcatum range at least as high as the Santonian Stage.

At Pueblo, only seven taxa that are present in the $S$. gracile Zone do not extend into the Turonian (this paper); Adnatosphaeridium? chonetum, Adnatosphaeridium tutulosum, Carpodinium obliquicostatum, Chichaouadinium vestitum (e.g., Plate 1, fig. 6), Pterodinium cingulatum ssp. reticulatum (e.g., Plate 1, fig. 4), Stephodinium coronatum and Valensiella reticulata. With the exception of Lower Turonian sample BC-33, this is also true of Prolixosphaeridium conulum. The stratigraphical distributions of A. tutulosum and $C$. obliquicostatum are dealt with above. There is little published information on the ranges of $A$ ? chonetum and $P$. conulum though the former has not previously been reported 


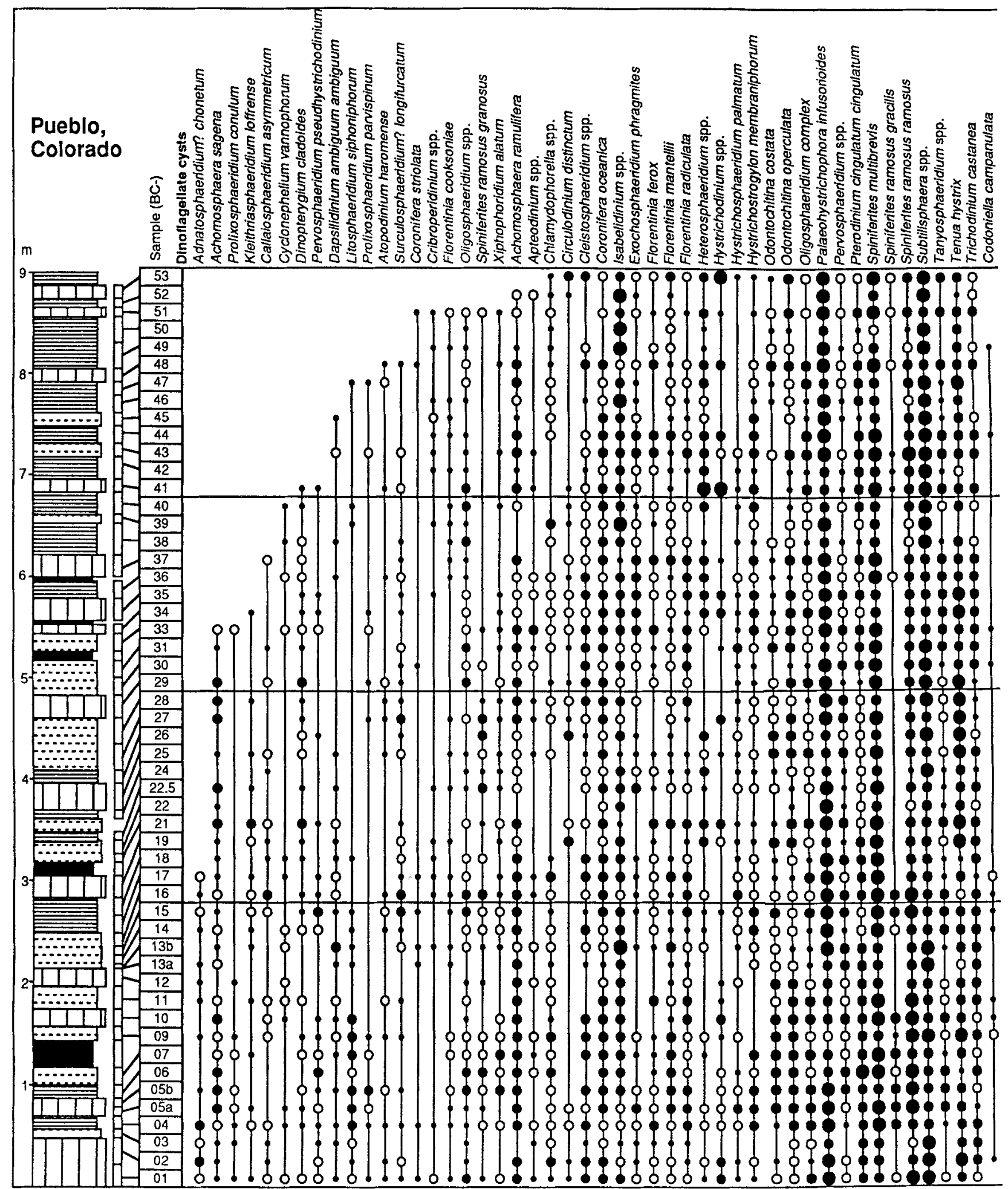

\begin{tabular}{|lllll|}
\hline$-20.3 \%$ & $0.0 .3 \% 100.7 \%$ & $-1.0 \%$ to $9.7 \%$ & $-10 \%+$ \\
\hline
\end{tabular} 


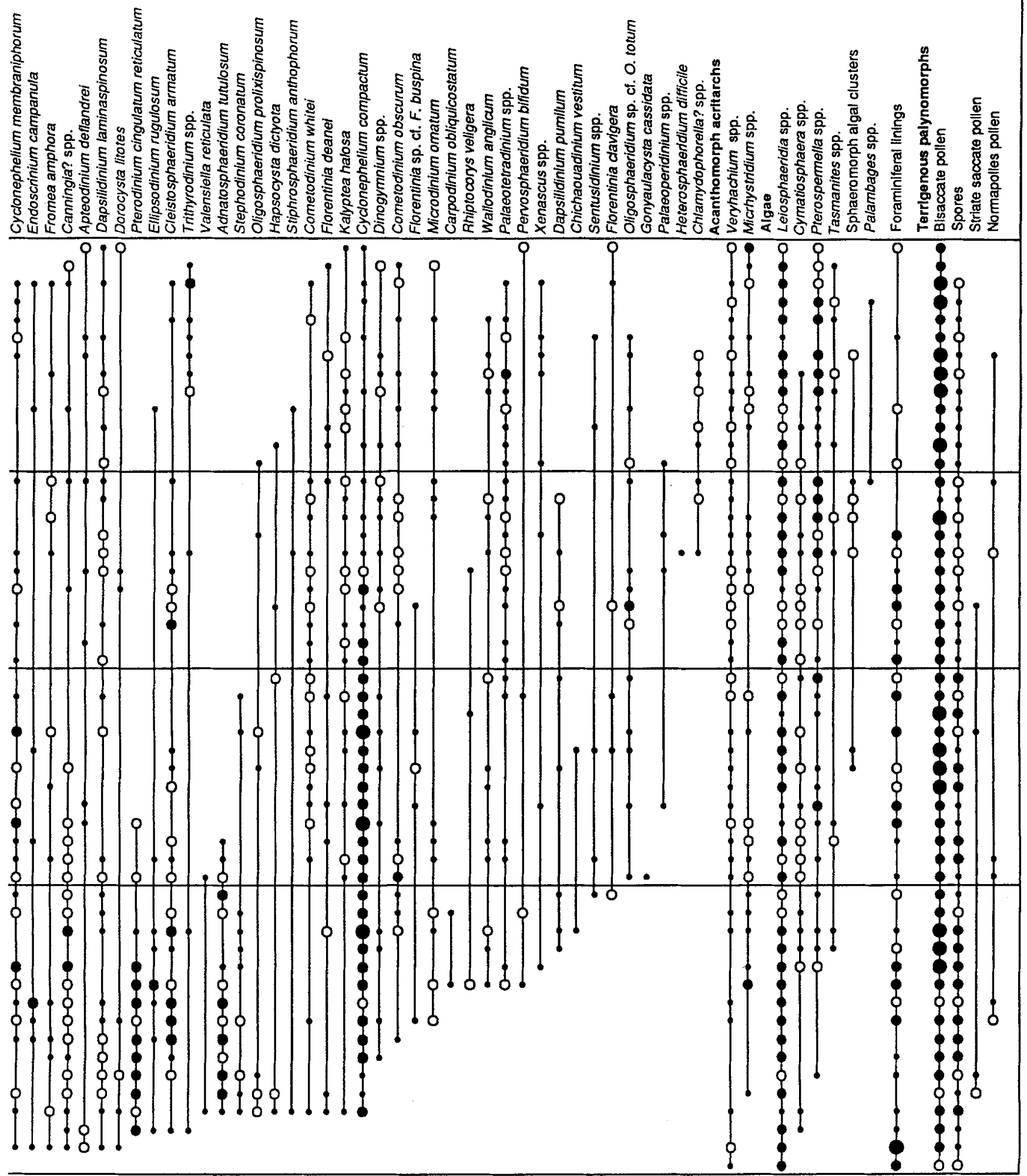

Fig. 6. The stratigraphical distribution of palynomorphs at Pueblo. For authors of species, dates of original descriptions and authors of emended diagnoses, see Williams et al. (1998). 


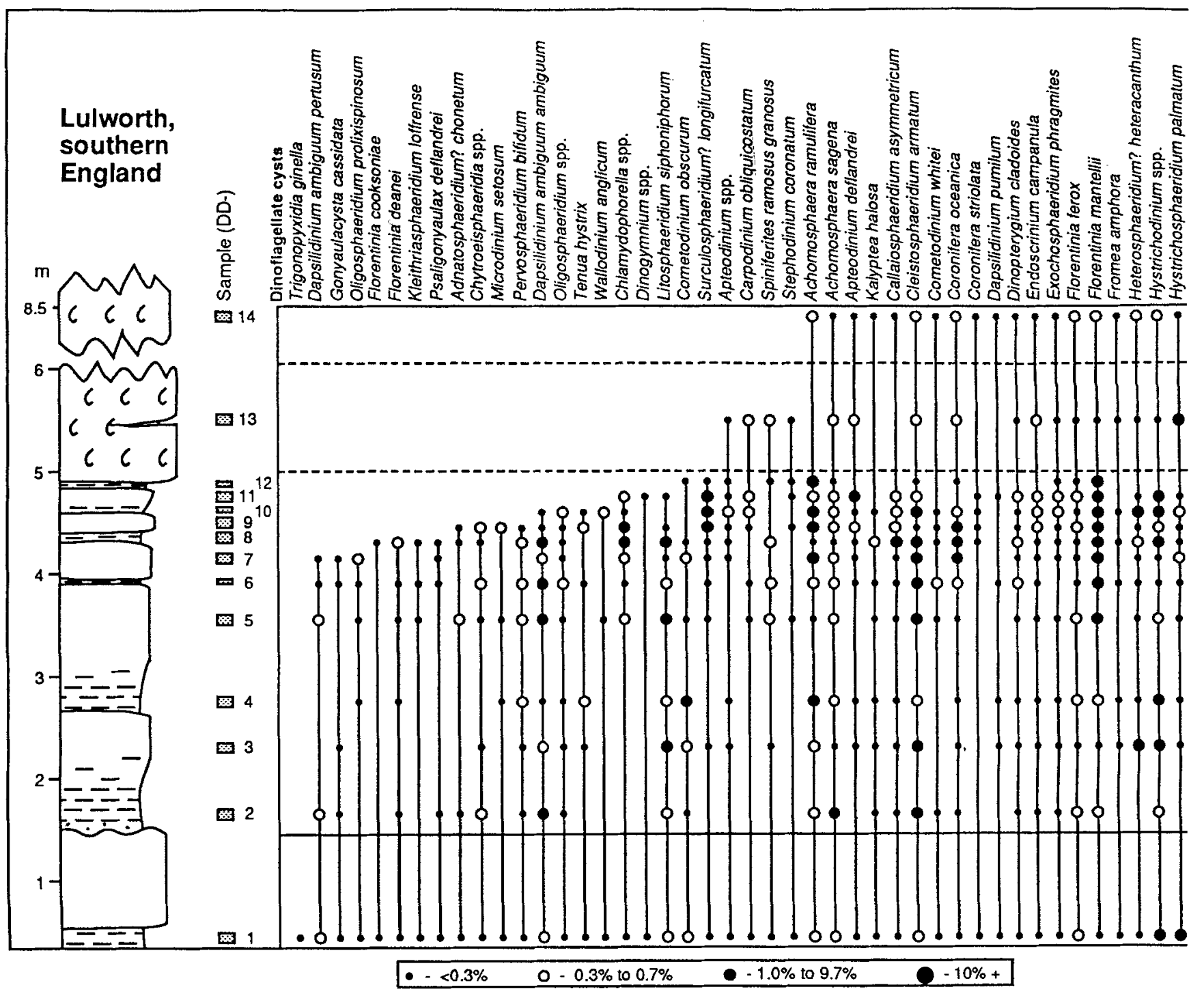

from above the Cenomanian. $P$. conulum has been reported as high as the Santonian in Germany (Yun, 1981) though possibly as reworking. $P$. cingulatum ssp. reticulatum and $S$. coronatum are known to range through the Turonian in other regions. Only two specimens of $C$. vestitum and $V$. reticulata were found at Pueblo (Fig. 6). C. vestitum has previously been thought to range from Upper Albian to Lower Cenomanian (Brideaux, 1971; Singh, 1971; Williams \& Bujak, 1988). Its occasional occurrence at Pueblo (from two samples) is thus higher than previously recorded. V. reticulata ranges into the Santonian in the North Sea Basin (Costa \& Davey, 1992).

\section{PALYNOLOGY AND PALAEOENVIRONMENTS}

Distribution of palynomorphs at Pueblo

Palynomorphs are moderately well-preserved throughout the Pueblo succession. In the more pure, micritic limestone beds (200-3000 per gram), they are often uncompressed. In the shaly interbeds (1000-17000 per gram) they are generally compressed/ flattened. Palynomorph concentration in shale beds is usually at least twice as high as that in adjacent limestones (Fig. 5). Samples from bentonites (BC-08, BC-20, BC-32, not illustrated) are palynologically barren.

Diverse assemblages of dinoflagellate cysts are present at Pueblo; 91 taxa were recorded. Palaeohystrichophora infusorioides and the Spiniferites Group are abundant in most samples through the succession (Fig. 10). Below the upper $W$. coloradoense Zone, Subtilisphaera spp. (including $S$. cheit, $S$ ? pirnaensis and $S$. pontis-mariae) generally composes $<30 \%$, and Isabelidinium spp. (mainly I. magnum) $<10 \%$, of assemblages. In the upper $W$. coloradoense and $M$. nodosoides Zones, their proportions are higher and they compose the marked increase in Peridiniineae (\%) noted at these levels (Fig. 4). Odontochitina spp., the Florentinia Group, Trichodinium castanea (Fig. 11) and Leiosphaeridia spp. (Fig. 4) are consistently common through the succession. The Cyclonephelium compactum-C. membraniphorum complex (e.g., Plate 1, fig. 8) is common to abundant (maximum 22\% in BC-19) in the $S$. gracile through mid $W$. coloradoense Zones (Fig. 11). Tenua hystrix has a high relative abundance (to $>20 \%$ ) in the Zones of 


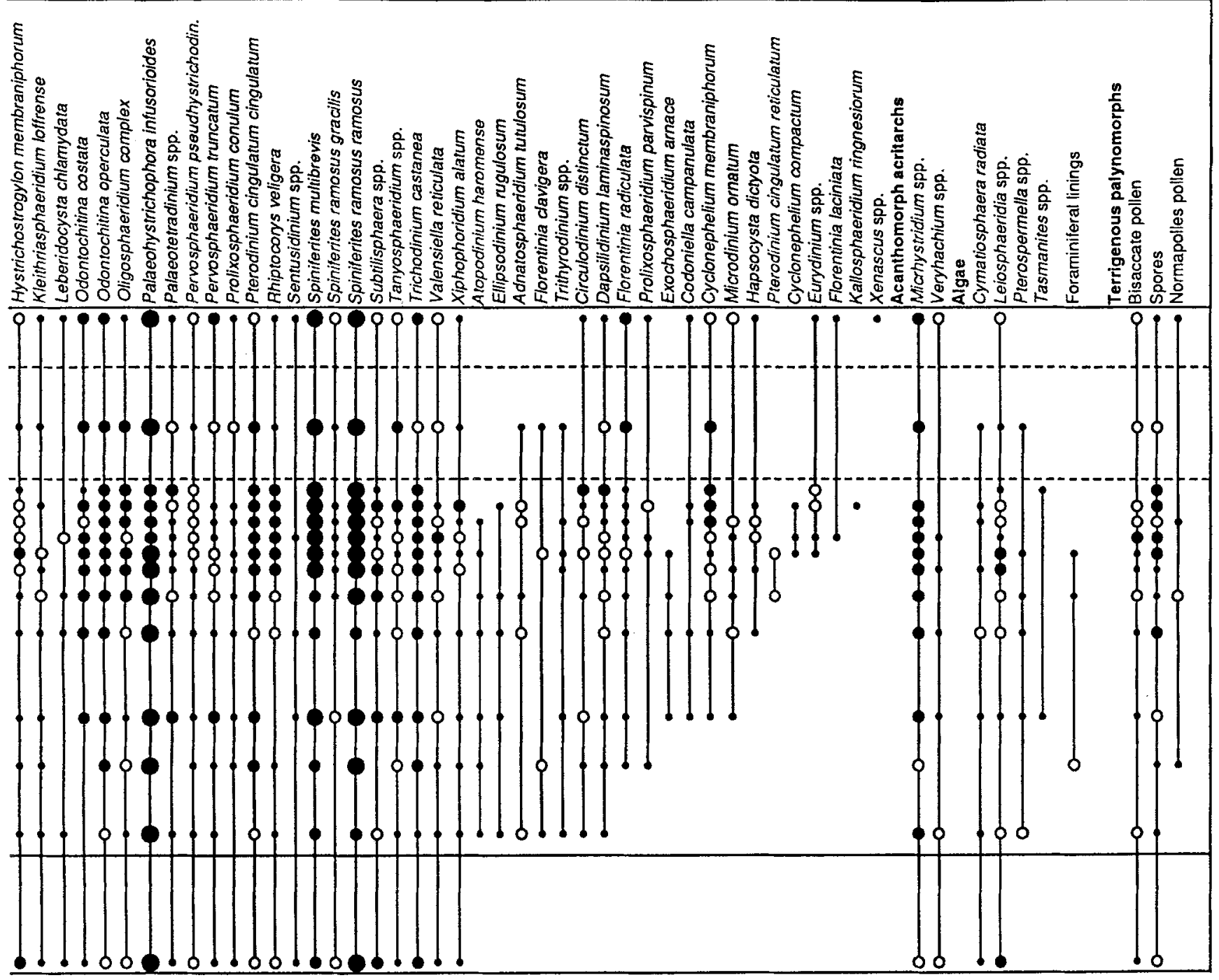

Fig. 7. The stratigraphical distribution of palynomorphs at Lulworth. For authors of species, dates of original descriptions and authors of emended diagnoses, see Williams et al. (1998).

$N$. juddii and $W$. coloradoense, particularly in the upper $N$. juddii Zone and at the Cenomanian-Turonian boundary (Fig. 11). Heterosphaeridium spp. ( $H$. sp. cf. $H$. conjunctum and $H$ ? heteracanthum) is relatively common $(2-16 \%)$ in the upper $W$. coloradoense and $M$. nodosoides Zones. Hystrichodinium spp. is sporadically common, notably in assemblages from beds 63,73 , $81,85,90,101,105$ and 109 , and tends to be associated with the limestone beds (cf. Fig. 1).

In Figure 5, the numbers of non-dominant dinoflagellate cyst taxa recorded in the Pueblo samples appear to correlate quite well with the numbers of specimens observed. There are no consistent absences of common or abundant taxa over any parts of the succession (Fig. 6), with the exceptions of Litosphaeridium siphoniphorum, Achomosphaera sagena, Adnatosphaeridium tutulosum and Pterodinium cingulatum ssp. reticulatum (see above). The absolute abundance of dinoflagellate cysts (and other palynomorphs) from both the shale and limestone lithologies of the $N$. juddii and $W$. coloradoense Zones is at least as high as that from similar lithologies in the $S$. gracile and $M$. nodosoides Zones below and above (Fig. 5). Thus, there does not appear to be any evidence for a marked reduction in the diversity of taxa that range through the interval, or for a collapse in the populations of cyst-forming dinoflagellates during the deposition of the uppermost Cenomanian - lowermost Turonian at Pueblo.

Land-derived (terrigenous) palynomorphs are mainly represented by gymnosperm bisaccate pollen. Pteridophyte spores are also common at some levels (Fig. 6). Rare angiosperm pollen (Tricolpites spp. and Normapolles pollen) are present. Terrigenous palynomorphs exhibit a rather variable distribution through the succession. They are abundant in the uppermost S. gracile Zone, beds 77 -lower 78 (20-50\% of assemblages) and, in particular, in the shale beds of the upper $N$. juddii Zone, beds 82-lower $85(30-60 \%)$. The latter level also contains the highest concentrations (2000-5000 per gram) recorded at Pueblo (Fig. 4). Terrigenous palynomorphs (bisaccate pollen associated with 


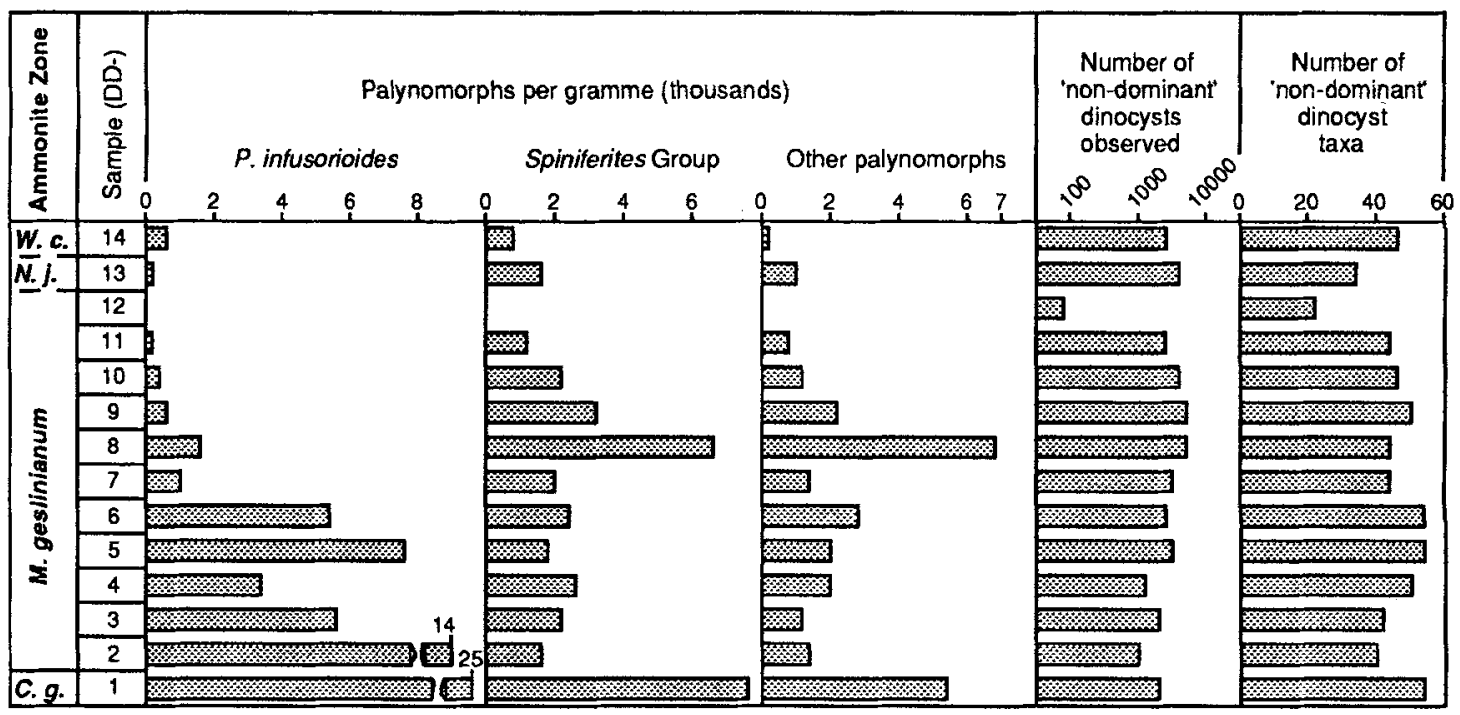

Fig. 8. Dinoflagellate cyst ('dinocyst') absolute abundance and diversity data from Lulworth.

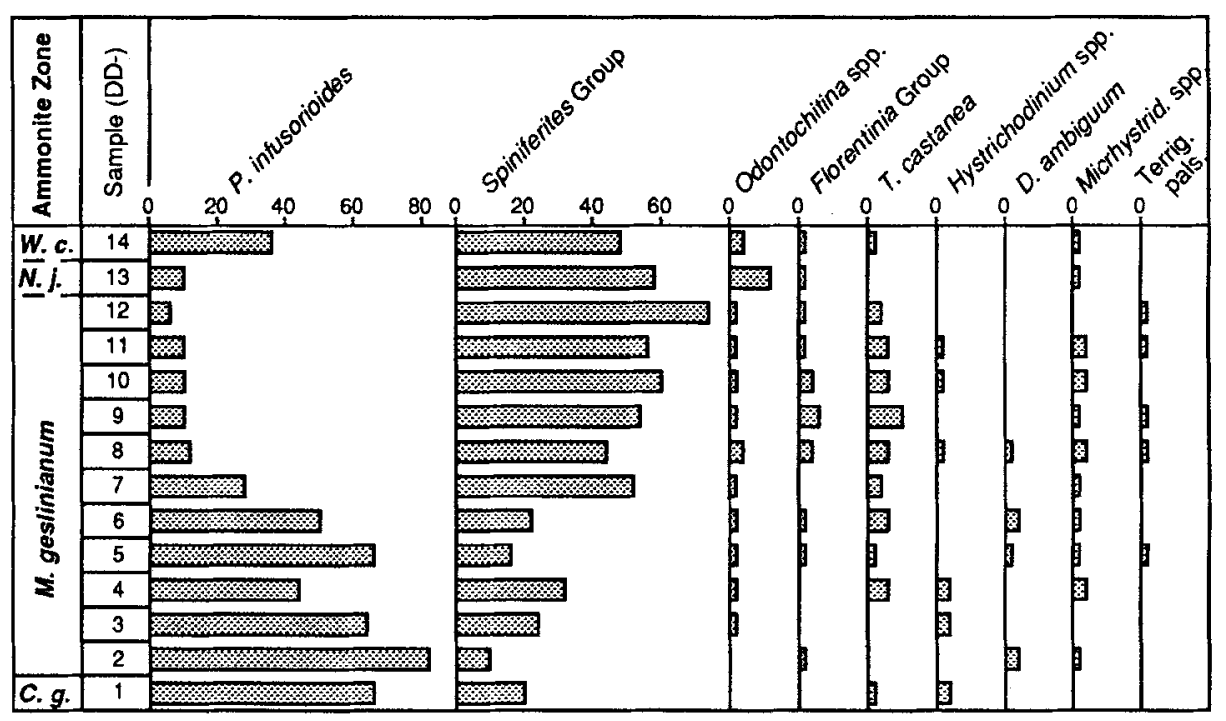

Fig. 9. Relative abundance $(\%)$ of common/abundant palynomorphs at Lulworth.

rare tetrads of Classopollis spp.) are abundant in some of the samples from the shale beds of the $M$. nodosoides Zone.

\section{Palaeoenvironmental interpretation at Pueblo}

The presence of 91 dinoflagellate cyst taxa at Pueblo, many of them cosmopolitan in distribution, confirms the likelihood of connected water masses between the Western Interior Seaway and the oceans to the south during the deposition of the lower and middle Bridge Creek Member (cf., Kauffman, 1984b; Eicher \& Diner, 1985; Leckie, 1985). Comparison of the Pueblo sample lithologies (Fig. 1), range chart (Fig. 6) and Figures 10 and 11, reveals that there do not seem to be any consistent differences in dinoflagellate cyst assemblage composition between shales and adjacent limestone beds (with the exception of the distribution of Hystrichodinium spp., see above). In the $N$. juddii, upper $W$. coloradoense and $M$. nodosoides Zones, terrigenous palynomorph proportions are, however, consistently higher in the shales. This observation could be considered to be in keeping with aspects of the dilution hypothesis for shale deposition (Pratt, 1984; Elder \& Kirkland, 1985; Arthur et al., 1986), i.e., the shales were deposited in response to intervals of increased supply of terrigenous clays and organic matter (including terrigenous palynomorphs), diluting the biogenic carbonate fraction. The greatest influxes of terrigenous clays, and the corresponding highest sedimentation rates for the Bridge Creek Member, have been inferred during the deposition of the $N$. juddii Zone in Colorado and Kansas (Elder \& Kirkland, 1985). The highest relative and absolute abundances of terrigenous palynomorphs are also found at this level at Pueblo (Fig. 4).

There is no evidence for a reduced diversity of dinoflagellate 


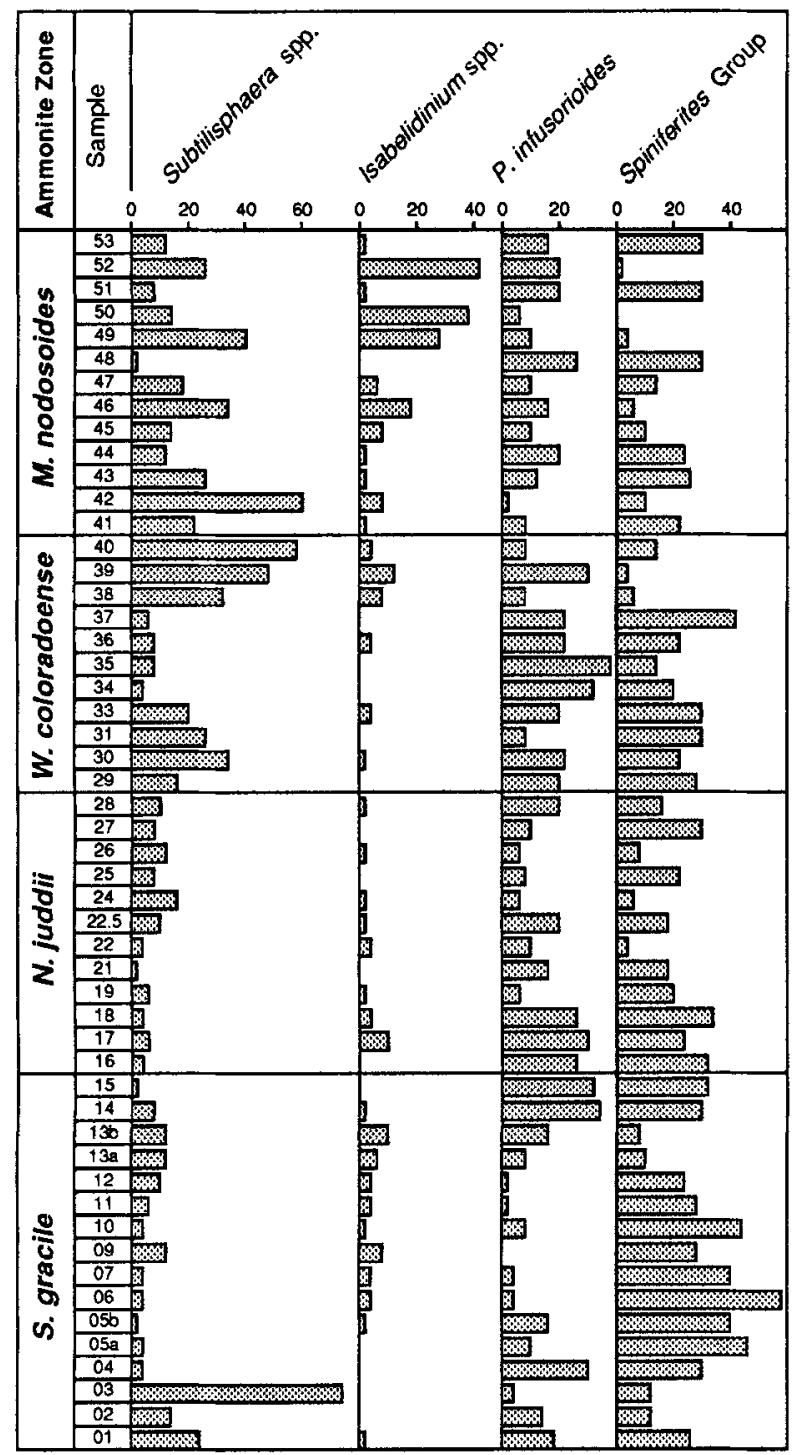

Fig. 10. Relative abundance $(\%)$ of the 'dominant' peridiniineaen (Subtilisphaera spp., Isabelidinium spp. and Palaeohystrichophora infusorioides) and gonyaulacineaen (Spiniferites Group) dinoflagellate cysts at Pueblo.

cysts in the shales relative to the limestones (cf., Figs 1, 5, 6). This was also found to be the case for calcareous nannofossils, Watkins $(1985,1986)$, and planktonic foraminifera, Eicher \& Diner $(1985,1989)$. These authors considered high diversities of calcareous nannofossils and planktonic foraminifera in the shale beds that they sampled to be consistent with normal marine surface waters during shale deposition. However, in a study of relatively closely spaced samples from the lower Bridge Creek Member, Leckie (1985) recorded anomalous large proportions of biserial planktonic foraminifera (Heterohelix spp.) in the $N$. juddii Zone (beds 78-85). He suggested that this shift in assemblage composition took place in response to the spread of subsaline surface waters during the deposition of the $N$.juddii Zone. This interpretation is in line with that given by Pratt (1985) for a corresponding isotope $\left(\delta^{18} \mathrm{O}\right)$ anomaly.

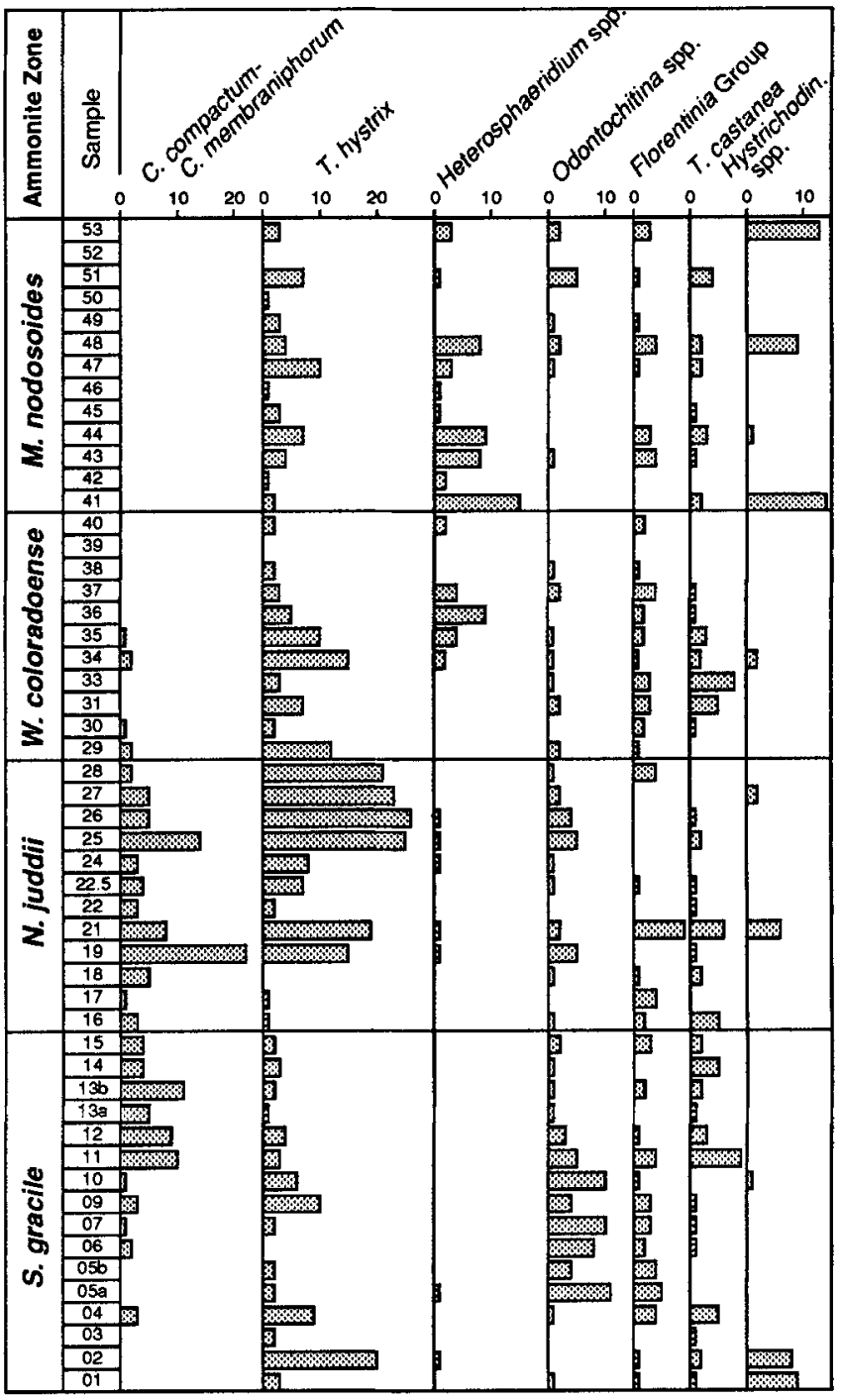

Fig. 11. Relative abundance (\%) of common/abundant gonyaulacineaen dinoflagellate cysts at Pueblo.

The high relative abundance of Cyclonephelium / Tenua dinoflagellate cyst morphotypes (Cyclonephelium compactumC. membraniphorum complex, c. 5-20\%; Tenua hystrix, c. 5$30 \%$ ) in the upper $M$. geslinianum to $N$. juddii Zones at Pueblo (Fig. 11), was also reported from correlative strata at three other Western Interior sections investigated by Li \& Habib (1996). Large proportions of Cyclonephelium/Tenua morphotypes are considered to be indicative of relatively restricted, coastal to near-shore environments (e.g., Brinkhuis \& Zachariasse, 1988; Harker et al., 1990, pp. 202-204). The Upper Cenomanian influx may signify a regressive pulse that led to an increase in the supply of relatively proximal dinoflagellate cyst populations, as suggested by Li \& Habib (1996). Alternatively, an increase in runoff could be invoked and would perhaps better account for the anomalous geochemical $\left(\delta^{18} \mathrm{O}\right)$ (Pratt, 1985) and planktonic foraminiferal data (Leckie, 1985). Reworking of mud to the basin (e.g., Jenkyns, 1980) and/or the formation of swamps due to drowning of land masses (cf., Ioannides et al., 1977) during 


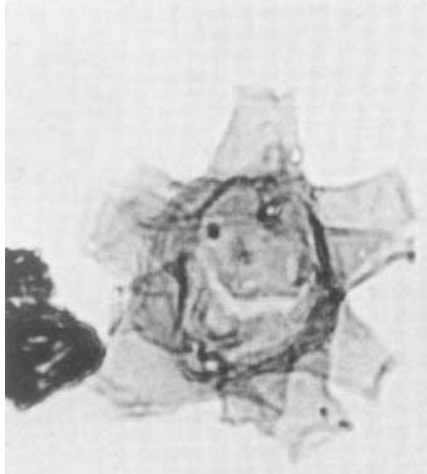

1

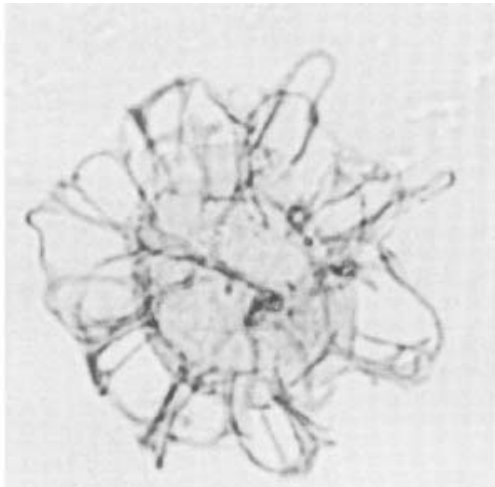

2

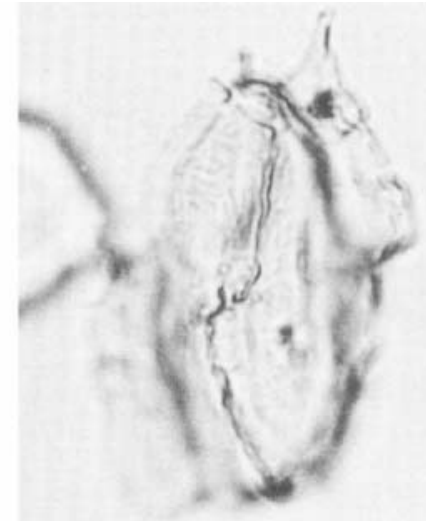

3

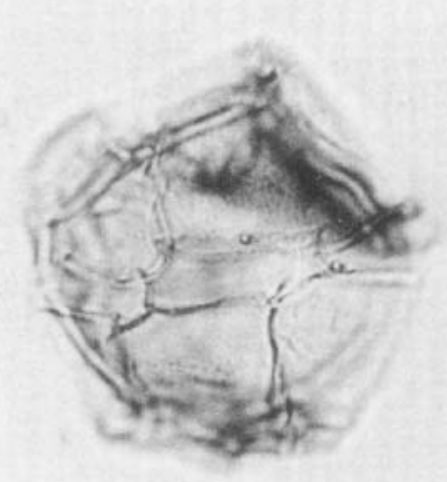

4
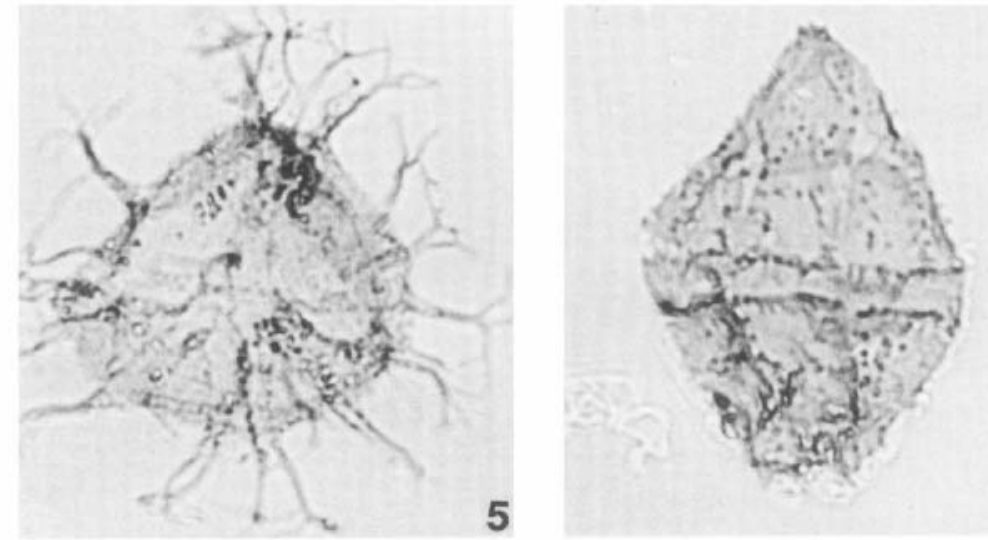

6

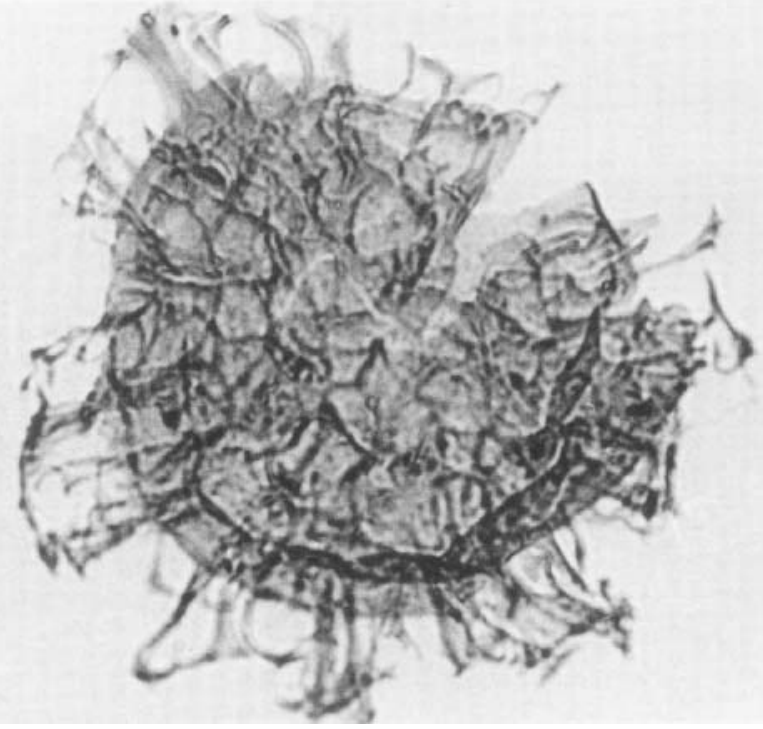

7

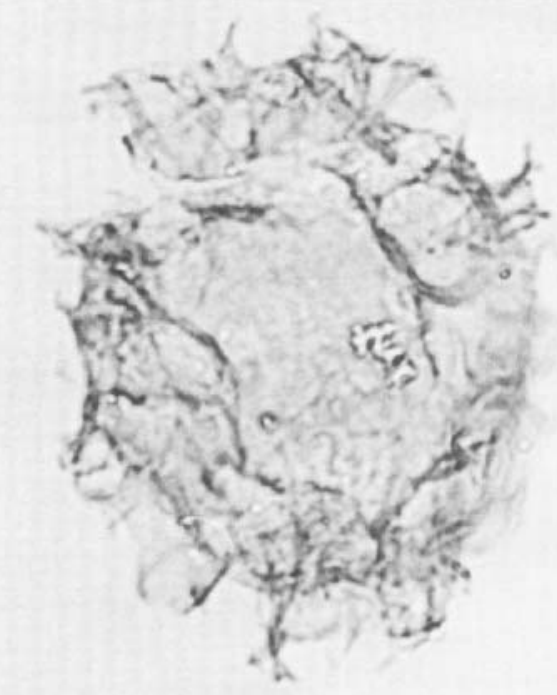

Explanation of Plate 1.

Cenomanian-Turonian dinoflagellate cysts from Pueblo and Lulworth. Figure captions include species name, author(s), locality, sample number, slide number and England Finder co-ordinates. All specimens are magnified at x800. fig. 1. Litosphaeridium siphoniphorum (Cookson \& Eisenack, 1958) Davey \& Williams, 1966, Pueblo, BC-04(A), M27/3. fig. 2. Adnatosphaeridium tutulosum (Cookson \& Eisenack, 1960) Morgan, 1980, Pueblo, BC-04(B), X30/1. fig. 3. Carpodinium obliquicostatum Cookson \& Hughes, 1964, Pueblo, BC-11(B), N34/0. fig. 4. Pterodinium cingulatum reticulatum (Davey \& Williams, 1966) Lentin \& Williams, 1981, Lulworth, DD-06(A), V39/1. fig. 5. Achomosphaera sagena Davey \& Williams, 1966, Pueblo, BC21(A), N35/2. fig. 6. Chichaouadinium vestitum (Brideaux, 1971) Bujak \& Davies, 1983, Pueblo, BC-13b(A), C38/1. fig. 7. Heterosphaeridium difficile (Manum \& Cookson, 1964) Ioannides, 1986, Pueblo, BC-36(B), S36/3. fig. 8. Cyclonephelium compactum - C. membraniphorum complex of Marshall \& Batten, 1988, Pueblo, BC-04(A), S27/1. 


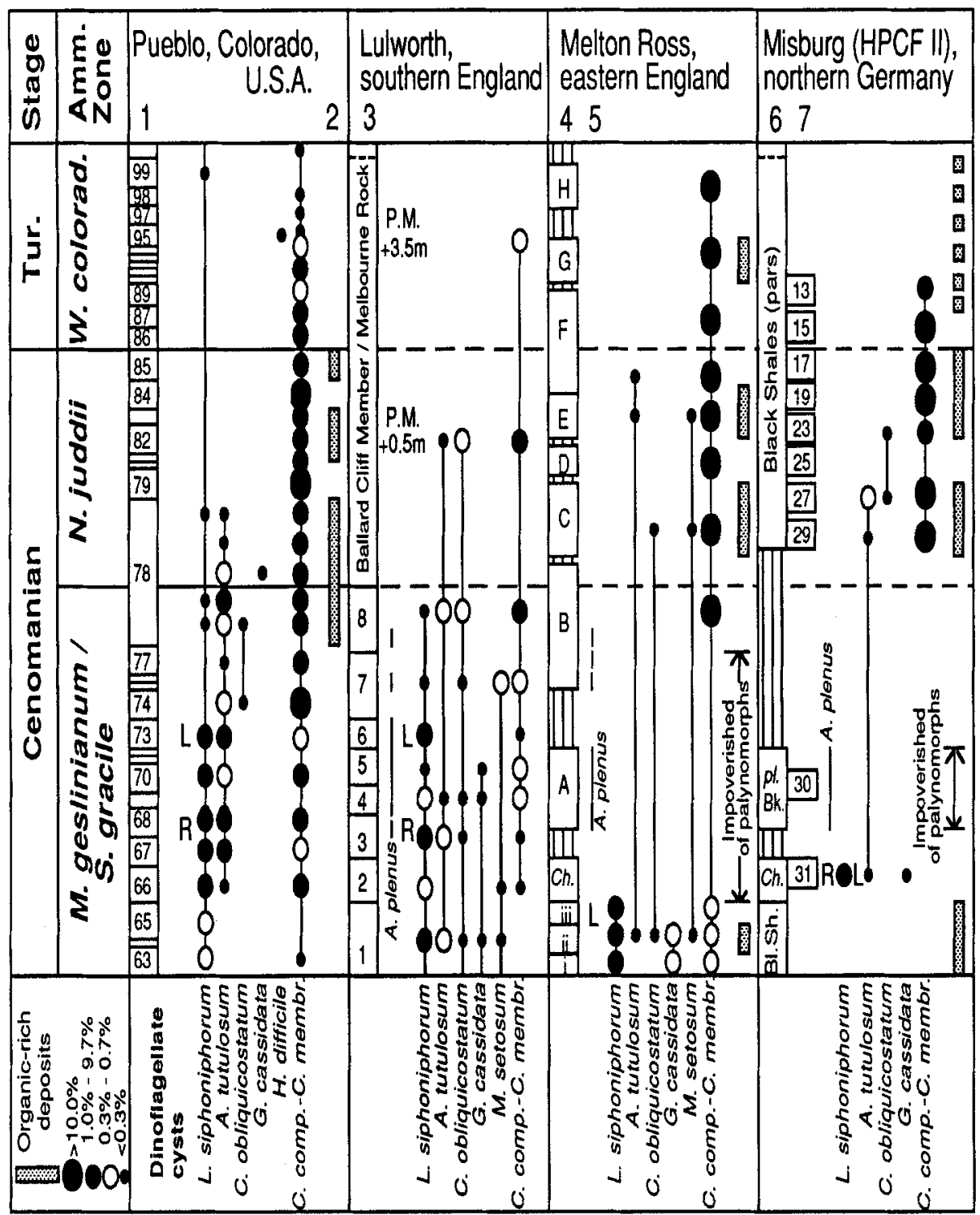

Fig. 12. The stratigraphical distribution of selected dinoflagellate cysts across the Cenomanian-Turonian boundary. 1 . Beds of Cobban \& Scott (1972); 2. Shales with anomalous $\delta^{18} \mathrm{O}$ values and Heterohelix spp. populations (see text); 3. Lithostratigraphical units of Jefferies (1963) and Gale (1996); 4. Beds A-H of Dodsworth (1996), triple-lines indicate probable hiatuses in this condensed section; 5 . Palynological data from Melton Ross (Dodsworth, in prep.); 6. Lithostratigraphical units of Ernst et al. (1984), Ch. = 'Chondrites Bed', pl. Bk. = 'plenus Bank'; 7 . Samples and data of Marshall \& Batten (1988). Notes: The top of consistent/common Litosphaeridium siphoniphorum ('L'), the range top of Rotalipora cushmani ('R') and the regional stratigraphical distribution of the belemnite Actinocamax plenus are indicated. In the English Channel, southern England (e.g., Lulworth) and northern France, Beds 1-8 constitute the Plenus Marls (M. geslinianum Zone). However, in the North Sea, north of the London-Brabant palaeohigh, the 'Plenus Marl Formation' of Deegan \& Scull (1977) is composed of deposits that are contiguous with some or all of the organic-rich and interbedded strata in eastern England and northern Germany ( $M$. gesIinianum $W$. coloradoense Zones).

transgression could also be invoked to account for the increase in terrigenous clays and palynomorphs at this level. It is noteworthy that abundant $C$. compactum - C. membraniphorum complex has also been reported from the uppermost Cenomanian - lowermost Turonian 'black shales' in northern Germany (Marshall \& Batten, 1988) and eastern England (Duane, in Hart et al., 1991, 1993; Dodsworth, 1996), as shown in Figure 12. This may signify an extra-basinal influence, possibly the widespread expansion and intensification of oxygen-minimum zones
(Schlanger \& Jenkyns, 1976), associated with the anomalous palaeoenvironmental conditions of the Cenomanian-Turonian boundary mass extinction interval/'oceanic anoxic event'.

\section{Lulworth}

All 14 samples from Lulworth yielded palynomorphs. These are well preserved in the lower part of the sampled section (DD-01 to DD-11) but are relatively poorly preserved in the upper part (DD-12 to DD-14), particularly in sample DD-12. Palynological 
recovery shows a broad up-section decrease from nearly 38000 per gram in DD-01 to just under 2000 per gram in DD-14. An exceptionally low value ( 111 per gram) was recorded from DD12.

Diverse assemblages of dinoflagellate cysts have been recorded from all of the samples analysed from Lulworth, including those from the upper part of the Plenus Marls (Fig. 7); 87 taxa were recorded. Palaeohystrichophora infusorioides dominates assemblages from the lower part of the succession, in samples DD-01 to -06 , while the Spiniferites Group dominates assemblages from the upper part, samples DD-07 to -14 (Fig. 9). Inspection of absolute abundance data (Fig. 8) reveals that the concentration of the Spiniferites Group in the samples follows a comparable pattern to that of the sum of other palynomorphs, the Spiniferites Group comprising approximately one half of the non- $P$. infusorioides assemblage. $P$. infusorioides itself, however, follows a markedly different pattern; its concentration declines through the Plenus Marls, particularly above Bed 4 (DD-06). Odontochitina spp., the Florentinia Group, Trichodinium castanea, Hystrichodinium spp., Dapsilidinium ambiguum (up to its range top) and the acanthomorph acritarch Micrhystridium spp. are consistently common through the succession (Fig. 9). Terrigenous palynomorphs comprise $<3 \%$ of assemblages.

In Figure 8, the numbers of non-dominant dinoflagellate cyst taxa recorded in the Lulworth samples appear to correlate quite well with the numbers of specimens observed. However, in spite of a general up-section increase in the latter, there appears to be a slight overall decrease in the former. This probably reflects the six regional range tops in the Plenus Marls discussed above. The 'shoulder' on the range chart in the upper part of the Plenus Marls (Fig. 7) partly reflects these range tops and the fact that there are only two sample positions above the Plenus Marls.

The section at Lulworth is unusual in that moderately good palynological recovery extends into the upper beds of the Plenus Marls and the overlying Ballard Cliff Member (Fig. 8). Although palynomorphs have been recovered from these levels in Sussex (Tocher, 1992; FitzPatrick, 1995) and the Isle of Wight (Clarke \& Verdier, 1967; Hart et al., 1987), yields are poor. FitzPatrick $(1995,1996)$ reported as few as 50 to just over 300 specimens from $50-80 \mathrm{~g}$ samples, i.e., $1-4$ per gram (assuming that all processed material was analysed), at Sussex and Isle of Wight localities. Further east, at the thinner (more winnowed?) successions at Dover (Tocher in Jarvis et al., 1988) and Cap Blanc Nez (Dodsworth, unpublished results), no palynomorphs have been recovered from some samples from the upper part of the Plenus Marls (Beds 7 and 8) and overlying few metres of chalk.

Poor recovery from the upper part of the Plenus Marls and Ballard Cliff Member (Melbourne Rock) probably reflects upward coarsening through the succession (Jeans et al., 1991; Lamolda et al., 1994) and the associated reduced palynomorph preservation potential of lithologies with a relatively high coarse silt and sand grade component. However, some authors (e.g., Jarvis et al., 1988; Lamolda et al., 1994; FitzPatrick, 1996; Hart, 1996) have attributed it to a collapse of cyst-forming dinoflagellate populations during environmental crisis in the contemporary world oceans. Many of the species that disappear in the upper part of the Plenus Marls are 'Lazarus taxa', i.e., they reappear in Turonian strata above the relatively coarse grained lithologies (Jarvis et al., 1988; FitzPatrick, 1996). The section at Lulworth could be considered in a population collapse hypothesis to have been deposited within a 'refugium', i.e., a relatively stable habitat during latest Cenomanian time in which cyst-forming dinoflagellates survived while intolerable environmental conditions prevailed in other parts of the basin.

Jarvis et al. (1988), Lamolda et al. (1994) and Paul \& Mitchell (1994) interpreted the upward coarsening through the Plenus Marls and Ballard Cliff Member (Melbourne Rock) to be the result of reduced coccolithophore productivity (coccoliths are a principal component of the fine fraction of chalk sediment). This is thought to be associated with a rise in relative sea level during the Cenomanian-Turonian boundary mass extinction interval/ 'oceanic anoxic event'. Hancock (1989) and Jeans et al. (1991) alternatively interpreted the upward coarsening to be the result of a regressive shift in facies in response to a fall in relative sea level. It is possible that changes in palaeobathymetry and/or environment led to the decline in the numerical importance of the dinoflagellate that produced the $P$. infusorioides cyst.

\section{CONCLUSIONS}

1. The top of consistent/common Litosphaeridium siphoniphorum (upper $M$. geslinianum $/ S$. gracile Ammonite Zone) is a distinctive inter-regional palaeontological event. It is recommended as a practicable datum for detecting the intra-Upper Cenomanian. The range tops of Adnatosphaeridium tutulosum and Carpodinium obliquicostatum appear to be reliable markers for the uppermost Cenomanian in the western interior of the USA and western Europe. The distributions of these fossils are apparently independent of the differing organic- and lithofacies in the depositional basins discussed.

2. The trans-Atlantic dinoflagellate cyst stratigraphy outlined here confirms correlations based on molluscs, planktonic foraminifera and $\delta^{13} \mathrm{C}$ geochemistry (Fig.12). It does not support the alternative correlation based on calcareous nannofossils proposed by Bralower (1988).

3. The presence of 91 dinoflagellate cyst taxa at Pueblo, many of which are cosmopolitan in distribution, confirms the likelihood of connected basin water masses between the Western Interior Seaway and the oceans to the south during Late Cenomanian and Early Turonian times.

4. In the upper $M$. geslinianum and $N$. juddii Zones at Pueblo, the high relative and absolute abundance of land-derived palynomorphs, along with large proportions of Cyclonephelium/Tenua dinoflagellate cyst morphotypes, is considered to be consistent with an increase in the supply of continental and nearshore elements. This is possibly a result of marked sea level change at this level though the palynological evidence is equivocal as to whether there was a sea level rise or fall.

5. If there was a fall in latest Cenomanian sea level, as suggested by Jeans et al. (1991), it was unlikely to have been of sufficient degree to sever connections between the Western Interior Seaway and southerly oceanic water masses. The compatibility of stratigraphies based upon disparate fossil groups and geochemistry $\left(\delta^{13} \mathrm{C}\right)$, suggests that a regression probably would not have led to basin compartmentalization within or between the Western Interior Seaway and western European areas.

6. In southern England, the impoverished dinoflagellate cyst 
assemblages in the uppermost Cenomanian-lowermost Turonian at some localities, are attributed to syn- or postdepositional oxidation of palynomorphs in the particularly coarse-grained lithologies at those localities (upper Plenus Marls and Ballard Cliff Member/Melbourne Rock).

7. The dinoflagellate cyst diversity and abundance of the beds sampled at Pueblo and Lulworth has been discussed. There is strong evidence that cyst-forming dinoflagellate populations continued to thrive during latest Cenomanian and earliest Turonian times in these basinal pelagic carbonate settings.

\section{ACKNOWLEDGEMENTS}

I thank Ted Spinner and Ken Dorning of Sheffield University for their support and helpfulness during the course of much of this research. Erle Kauffman kindly supplied the rock samples from Pueblo. Discussions with other colleagues, in particular Graham Booth, Ailbhe Duane, Jane Evans, Jim Fenton, John Fitzgerald, Malcolm Hart, Nicky Hine, Jake Jacovides, Keith Marshall, Duncan McLean, Steve Packer, Keith Paramor, Stuart Sutherland, Ron Woollam and Donata Zucchi have been most beneficial. David Batten and Keith Gueinn recommended improvements to earlier expanded drafts of the manuscript.

\section{Manuscript received 12 April 1999 Manuscript accepted 25 October 1999}

\section{REFERENCES}

Arthur, M. A., Bottjer, D. J., Dean, W. E., Fischer, A. G., Hattin, D. E., Kauffman, E. G., Pratt, L. M. \& Scholle, P. A. 1986. Rhythmic bedding in Upper Cretaceous pelagic carbonate sequences: Varying sedimentary response to climatic forcing. Geology, 14: 153-156.

Aurisano, R. W. 1989. Upper Cretaceous dinoflagellate biostratigraphy of the subsurface Atlantic coastal plain of New Jersey and Delaware, U.S.A. Palynology, 13: 143-179.

Bengtson, P. 1996. The Turonian stage and substage boundaries. In: Rawson et al. (Eds) Proceedings, 'Second International Symposium on Cretaceous Stage Boundaries', Brussels 8-16 September 1995. Bulletin de l'Institut Royal des Sciences Naturelles de Belgique - Sciences de la Terre, No. 66 - Supplement, 69-79.

Bralower, T. J. 1988. Calcareous nannofossil biostratigraphy and assemblages of the Cenomanian-Turonian boundary interval: implications for the origin and timing of oceanic anoxia. Paleoceanography, 3 ; 275-316.

Brideaux, W. W. 1971. Palynology of the Lower Colorado Group, Central Alberta, Canada. I. Introductory remarks, geology, and microplankton studies. Palaeontographica Abt. B, 135: 53-114.

Brinkhuis, H. \& Zachariasse, W. J. 1988. Dinoflagellate cysts, sea level changes and planktonic foraminifers across the Cretaceous-Tertiary boundary at El Haria, N.W. Tunisia. Marine Micropaleontology, 13: 153-191.

Carter, D. J. \& Hart, M. B. 1977. Aspects of mid-Cretaceous stratigraphical micropalaeontology. Bulletin of the British Museum, Natural History (Geology), 29: 1-135.

Clarke, R. F. A. \& Verdier, J.-P. 1967. An investigation of microplankton assemblages from the Chalk of Isle of Wight, England. Verhandelingen der Koninklijke Nederlandsche Akademie van Wetenschappen, Afdeling Natuurkunde, Eerste Reeks, 24: 1-96.

Cobban, W. A. \& Scott, G. R. 1972. Stratigraphy and ammonite fauna of the Graneros Shale and Greenhorn Limestone near Pueblo, Colorado. Geological Survey Professional Paper, 645: 1-108. Washington.

Costa, L. I. \& Davey, R. J. 1992. Dinoflagellate cysts of the Cretaceous System. In: Powell, A. J. (Ed.) A Stratigraphic Index of Dinoflagellate Cysts. Chapman \& Hall, London, 99-131.

Courtinat, B. 1993. The significance of palynofacies fluctuations in the Greenhorn Formation (Cenomanian-Turonian) of the Western Interior Basin, USA. Marine Micropaleontology, 21: 249-257.

Courtinat, B., Crumière, J.-P., Méon, H. \& Schaaf, A. 1991. Les associations de kyst de dinoflagellés du Cénomanien-Turonien de
Vergons (Bassin Vocontien France), Geobios, 24: 649-666.

Davey, R. J. 1969 . Non-calcareous microplankton from the Cenomanian of England, northern France and North America, Part I. Bulletin of the British Museum (Natural History) Geology, 17: 103-180.

Davey, R. J. \& Verdier, J. P. 1971. An investigation of microplankton assemblages from the Albian of the Paris Basin. Verhandelingen der Koninklijke Nederlandse Akademie van Wetenschappen, Afdeling Natuurkunde, Eerste Reeks, 26: 1-58.

Davey, R. J. \& Verdier, J. P. 1976. A review of certain non-tabulate Cretaceous hystrichospherid dinocysts. Review of Palaeobotany and Palynology, 22: 307-335.

Deegan, C. E. \& Scull, B. J. 1977. A standard lithostratigraphic nomenclature for the Central and Northern North Sea. Institute of Geological Sciences Report 77/25; NPD-Bulletin No. 1

Dodsworth, P. 1995. A note of caution concerning the application of quantitative palynological data from oxidized preparations. Journal of Micropalaeontology, 14: 6 .

Dodsworth, P. 1996. Stratigraphy, microfossils and depositional environments of the lowermost part of the Welton Chalk Formation (late Cenomanian to early Turonian, Cretaceous) in eastern England. Proceedings of the Yorkshire Geological Society, 51: 45-64.

Eicher, D. L. \& Diner, R. 1985. Foraminifera as indicators of water mass in the Cretaceous Greenhorn Sea, Western Interior. In: Pratt, L. M., Kauffman, E. G. \& Zelt, F. B. (Eds) Fine-grained Deposits and Biofacies of the Cretaceous Western Interior Seaway. Society of Economic Paleontologists and Mineralogists, Field Trip Guide Book No. 4, 60-71. Eicher, D. L. \& Diner, R. 1989. Origin of the Cretaceous Bridge Creek cycles in the Western Interior, United States. Palaeogeography, Palaeoclimatology, Palaeoecology, 74: 127-146.

Elder, W. P. \& Kirkland, J. I. 1985. Stratigraphy and depositional environments of the Bridge Creek Limestone Member of the Greenhorn Limestone at Rock Canyon Anticline near Pueblo, Colorado. In: Pratt, L. M., Kauffman, E. G. \& Zelt, F. B. (editors) Fine-grained Deposits and Biofacies of the Cretaceous Western Interior Seaway. Society of Economic Paleontologists and Mineralogists, Field Trip Guide Book No. 4, 122-134.

Ernst, G., Wood, C. J. \& Hilbrecht, H. 1984. The Cenomanian-Turonian boundary problem in NW-Germany with comments on the north-south correlation to the Regensburg Area. Bulletin of the Geological Society of Denmark, 33: 103-113.

FitzPatrick, M. E. J. 1995. Dinoflagellate cyst biostratigraphy of the Turonian (Upper Cretaceous) of southern England. Cretaceous Research, 16: 757-791.

FitzPatrick, M. E. J. 1996. Recovery of Turonian dinoflagellate cyst assemblages from the effects of the oceanic anoxic event at the end of the Cenomanian in southern England. In: Hart, M. B. (ed.) Biotic Recovery from Mass Extinction Events. Geological Society, London, Special Publications 102, 279-297.

Foucher, J.-C. 1979. Distribution stratigraphique des kystes de Dinoflagellés et des Acritarches dans le Crétacé supérieur du Bassin de Paris et de l'Europe septentrionale. Palaeontographica Abt. B, 169: 78-105.

Foucher, J.-C. 1980. Dinoflagellés et Acritarches dans le Crétacé du Boulonnais. In: Robaszynski, F., Amédro, F., Foucher, J.C., Gaspard, D., Magniez, F., Manivit, H. \& Sornay, J. Sythèse biostratigraphique de l'Aptien au Santonien du Boulonnais, à partir de sept groupes paléontologiques: Foraminifères, nannoplancton, Dinoflagellés et macrofaunes - Zonations micropaléontologiques intégrées dans le cadre du Crétacé boréal nord-européen. Revue de Micropaléontologie, 22: 233, 288-297, 310-311.

Foucher, J.-C. 1981. Kystes de Dinoflagellés du Crétacé Moyen Européen: Proposition d'une Echelle Biostratigraphique pour le Domaine Nordoccidental. Cretaceous Research, 2: 331-338.

Foucher, J-C. 1982. Dinoflagells et Acritarches du Turonien stratotypique (affleurments du Saumurois, sondage de Civray-de-Touraine). In: Robaszynski, F., Alcaydé, G., Amédro, F., Badillet, G., Damotte, R., Foucher, J.-C., Jardiné, S., Legoux, O., Manivit, H., Monciardini, C. \& Sornay, J. Le Turonien de la Région-type: Saumurois et Touraine. Stratigraphie, biozonations, sédimentologie. Bull. Centres Rech. Explor. Prod. Elf-Aquitaine, 6: 147-150, 171-173, 176.

Gale, A. S. 1996. Turonian correlation and sequence stratigraphy of the Chalk in southern England. In: Hesselbo, S. P. \& Parkinson, D. N. (Eds) Sequence Stratigraphy in British Geology. Geological Society, London, Special Publications 103, 177-195.

Gale, A. S., Jenkyns, H. C., Kennedy, W. J. \& Corfield, R. M. 1993 Chemostratigraphy versus biostratigraphy: data from around the Cenomanian-Turonian boundary. Journal of the Geological Society. London, 150: 29-32.

Hancock, J. M. 1989. Sea level changes in the British region during the Late Cretaceous. Proceedings of the Geologists' Association, 100: 565-594.

Harker, S. D., Gustav, S. H. \& Riley, L. A. 1987. Triassic to Cenomanian stratigraphy of the Witch Ground Graben. In: Brooks, S. J. \& Glennie, 
K. (Eds) Petroleum Geology of North-West Europe. Graham \& Trotman, London, 809-818.

Harker, S. D., Sarjeant, W. A. S. \& Caldwell, W. G. E. 1990, Late Cretaceous (Campanian) organic-walled microplankton from the Interior Plains of Canada, Wyoming and Texas: biostratigraphy, palaeontology and environmental interpretation. Palaeontographica Abt. B, 219: 1243.

Harland, R. 1973. Dinoflagellate cysts and acritarchs from the Bearpaw Formation (Upper Campanian) of Southern Alberta, Canada. Palaeontology, 16: 665-706.

Harries, P. J. 1993. Dynamics of survival following the CenomanianTuronian (Upper Cretaceous) mass extinction event. Cretaceous Research, 14: 563-583.

Hart, M. B. 1996. Recovery of the food chain after the Late Cenomanian extinction event. In: Hart, M.B. (Ed.) Biotic Recovery from Mas. Extinction Events. Geological Society, London, Special Publication 102, 265-277.

Hart, M. B., Dodsworth, P., Ditchfield, P. W., Duane, A. M. \& Orth, C. J. 1991. The late Cenomanian event in eastern England. Historical Biology, 5: $339-354$

Hart, M. B., Dodsworth, P. \& Duane, A. M. 1993. The late Cenomanian event in eastern England. Cretaceous Research, 14: 495-508.

Hart, M. B. \& Leary, P. N. 1991. Stepwise mass extinctions: the case for the late Cenomanian event. Terra Nova, 3: 142-147.

Hart, M. B., Weaver, P. P. E., Clements, R. G., Burnett, J. A., Tocher, B. A., Batten, D. J., Lister, J. K. \& MacLennan, A. M. 1987. The Isle of Wight. Cretaceous. In: Lord, A. R. \& Bown, P. R. (Eds) Mesozoic and Cenozoic Stratigraphical Micropalaeontology of the Dorset Coast and Isle of Wight, Southern England. British Micropalaeontological Society Guide Book 1, 88-149.

Hattin, D. E. 1975. Stratigraphy and depositional environment of Greenhorn Limestone (Upper Cretaceous) of Kansas. Kansas Geological Survey Bulletin, 209.

Hilbrecht, H., Arthur, M. A. \& Schlanger, S. O. 1986. The CenomanianTuronian boundary event: sedimentary, faunal and geochemical criteria developed from stratigraphic studies in NW-Germany. In: Walliser, $\mathrm{H}$ O. (Ed.) Global Bio-Events. Lecture Notes Earth Sciences 8: 345-351.

Ioannides, N. S., Stavrinos, G. N. \& Downie, C. 1976. Kimmeridgian microplankton from Clavell's Hard, Dorset, England. Micropaleontology, 22: 443-478.

Jarvis, I., Carson, G. A., Cooper, K., Hart, M. B., Horne, D., Leary, P. N. Rosenfeld, A. \& Tocher, B. A. 1988. Chalk microfossil assemblages and the Cenomanian-Turonian (late Cretaceous) oceanic anoxic event, new data from Dover, England. Cretaceous Research, 9: 3-103.

Jeans, C. V., Long, D., Hall, M. A., Bland, D. J. \& Cornford, C. 1991. The geochemistry of the Plenus Marls at Dover, England: evidence of fluctuating oceanographic conditions and of glacial control during the development of the Cenomanian-Turonian $\delta^{13} \mathrm{C}$ anomaly. Geological Magazine, 128: 604-632.

Jefferies, R. P. S. 1963. The Stratigraphy of the Actinocamax plenus Subzone (Turonian) in the Anglo-Paris Basin. Proceedings of the Geologists' Association, 74: 1-30.

Jenkyns, H. C. 1980 . Cretaceous anoxic events: from continents to oceans. Journal of the Geological Society, London, 137: 171-188.

Kauffman, E. G. 1984a. The fabric of Cretaceous marine extinctions. In: Berggren, W. A. \& Van Couvering, J. (Eds) Catastrophes and Earth History: the New Uniformitarianism. Princeton, N.J. Princeton University Press, $151-246$.

Kauffman, E. G. 1984b. Paleobiogeography and evolutionary response dynamic in the Cretaceous Western Interior Seaway of North America. In: Westermann, G. E. G. (ed.) Jurassic-Cretaceous Biochronology and Paleogeography of North America. Geological Association of Canada, Special Paper, 27, 273-306.

Kennedy, W. J. \& Cobban, W. A. 1991. Stratigraphy and interregional correlation of the Cenomanian-Turonian transition in the Western Interior of the United States near Pueblo, Colorado, a potential boundary stratotype for the base of the Turonian stage. Newsletters on Stratigraphy, 24: 1-33.

Lamolda, M. A., Gorostidi, A. \& Paul, C. R. C. 1994. Quantitative estimates of calcareous nannofossil changes across the Plenus Marls (latest Cenomanian), Dover, England: implications for the generation of the Cenomanian-Turonian Boundary Event. Cretaceous Research, 15: $143-164$.

Lamolda, M. A. \& Mao, S. 1999. The Cenomanian-Turonian boundary event and dinocyst record at Ganuza (northern Spain). Palaeogeography, Palaeoclimatology, Palaeoecology, 150: 65-82.

Leary, P. N. \& Peryt, D. 1991. The late Cenomanian oceanic anoxic even in the western Anglo-Paris Basin and southeast Danish-Polish Trough: survival strategies of and recolonisation by benthonic foraminifera. Historical Biology, 5; 321-338.
Leckie, R. M. 1985. Foraminifera of the Cenomanian-Turonian boundary interval, Greenhorn Formation, Rock Canyon Anticline, Pueblo, Colorado. In: Pratt, L. M., Kauffman, E. G. \& Zelt, F. B. (Eds) Finegrained Deposits and Biofacies of the Cretaceous Western Interior Seaway. Society of Economic Paleontologists and Mineralogists, Field Trip Guide Book No. 4, 139-150.

Li, H. \& Habib, D. 1996. Dinoflagellate stratigraphy and its response to sea level change in Cenomanian-Turonian sections of the Western Interior of the United States. Palaios, 15: 15-30.

Mao, S. \& Lamolda, M. A. 1999. Quistes de dinoflagelados del Cenomaniense superior y Turoniense inferior de Ganuza, Navarra, II. - Biostratigrafia. Revista Española de Paleontologia, no. extr. Homenaje al Prof. J. Truyols, 195-203.

Marshall, K. L. \& Batten, D. J. 1988. Dinoflagellate cyst associations in Cenomanian-Turonian 'Black Shale' sequences of northern Europe. Review of Palaeobotany and Palynology, 54: 85-103.

McMinn, A. 1988. Outline of a Late Cretaceous dinofiagellate zonation of northwestern Australia. Alcheringa, 12: 137-156.

Morgan, R. 1980. Palynostratigraphy of the Australian Early and Middle Cretaceous. Geological Survey of New South Wales, Palaeontology Memoir, 18: 1-153.

Nuñez-Betelu, K. \& Hills, L.V. 1995. Palynological and rock-eval/TOC pyrolysis indicators of the Cenomanian/Turonian boundary in the Canadian Arctic. In: Second International Symposium on Cretaceous Stage Boundaries (Abstract Volume), Brussels, September 1995, 87.

Paul, C. R. C. \& Mitchell, S. F. 1994. Is famine a common factor in marine mass extinctions? Geology, 22: 679-682.

Pratt, L. M. 1984. Influence of paleoenvironmental factors on preservation of organic matter in middle Cretaceous Greenhorn Formation, Pueblo, Colorado. American Association of Petroleum Geologists, Bulletin, 68: $1146-1159$

Pratt, L. M. 1985. Isotopic studies of organic matter and carbonate in rocks of the Greenhorn marine cycle. In: Pratt, L. M., Kauffman, E. G. \& Zelt, F. B. (Eds) Fine-grained Deposits and Biofacies of the Cretaceous Western Interior Seaway. Society of Economic Paleontologists and Mineralogists, Field Trip Guide Book No. 4, 38-48.

Raup, D. M. \& Sepkoski, J. J. Jr. 1982. Mass extinctions in the marine fossil record. Science, 215: 1501-1503.

Rawson, P. F., Dhondt, A. V., Hancock, J. M. \& Kennedy, W. J. (Eds) 1996. Proceedings, 'Second International Symposium on Cretaceous Stage Boundaries', Brussels 8-16 September 1995. Bulletin de l'Institut Royal des Sciences Naturelles de Belgique - Sciences de la Terre No. 66 Supplement, $117 \mathrm{pp}$.

Schlanger, S. O. \& Jenkyns, H. C. 1976. Cretaceous oceanic anoxic events: causes and consequences. Geologie en Mijnbouw, 55: 179-184

Scholle, P. A. \& Arthur, M. A. 1980. Carbon isotope fluctuations in Cretaceous pelagic limestones: potential stratigraphic and petroleum exploration tool. American Association of Petroleum Geologists Bulletin, 64: $67-87$

Singh, C. 1971. Lower Cretaceous microfloras of the Peace River area, northwestern Alberta. Research Council of Alberta, Bulletin 28

Tocher, B. A. 1992. The Cenomanian-Turonian (Late Cretaceous) oceanic anoxic event: a comparison of dinoflagellate cyst distributions from sections in southern England. (Abstract). Palynology, 16: 232.

Tocher, B. A. \& Jarvis, I. 1987. Dinoflagellate cysts and stratigraphy of the Turonian (Upper Cretaceous) chalk near Beer, southeast Devon, England. In: Hart, M. B. (Ed.) Micropalaeontology of Carbonate Environments. Ellis Horwood Ltd., Chichester, 138-175.

Tocher, B. A. \& Jarvis, I. 1995. Dinocyst distributions and stratigraphy of two Cenomanian-Turonian boundary (Upper Cretaceous) sections from the western Anglo-Paris Basin. Journal of Micropalaeontology, 14: 97105.

Watkins, D. K. 1985. Biostratigraphy and paleoecology of calcareous nannofossils in the Greenhorn marine cycle. In; Pratt, L. M., Kauffman, E. G. \& Zelt, F. B. (Eds) Fine-grained Deposits and Biofacies of the Cretaceous Western Interior Seaway. Society of Economic Paleontologists and Mineralogists, Field Trip Guide Book No. 4, 151-156.

Watkins, D. K. 1986. Calcareous nannofossil paleoceanography of the Greenhorn Sea, Geological Society of America, Bulletin 97: 1239-1249.

Williams, G. L. \& Bujak, J. P. 1988. Mesozoic and Cenozoic dinoflagellates, In: Bolli, H. M., Saunders, J. B. \& Perch-Nielsen, K. (Eds) Plankton Stratigraphy. Cambridge Earth Science Series. Cambridge University Press, 847-964.

Williams, G. L., Lentin, J. K. \& Fensome, R. A. 1998. The Lentin \& Williams Index of Fossil Dinoflagellates 1998 edition. A.A.S.P. Contribution Series, Number 34, $817 \mathrm{pp}$.

Yun, H-S. 1981. Dinoflagellaten aus der Oberkreide (Santon) von Westfalen. Palaeontographica Abt. B, 177: 1-89. 